\title{
Characteristics, Origins, and Impacts of Summertime Extreme Precipitation in the Lake Mead Watershed
}

\author{
Michael D. Sierks, Julie Kalansky, Forest Cannon, And F. M. RAlPH \\ Scripps Institution of Oceanography, University of California, San Diego, La Jolla, California
}

(Manuscript received 28 May 2019, in final form 11 September 2019)

\begin{abstract}
The North American monsoon (NAM) is the main driver of summertime climate variability in the U.S. Southwest. Previous studies of the NAM have primarily focused on the Tier I region of the North American Monsoon Experiment (NAME), spanning central-western Mexico, southern Arizona, and New Mexico. This study, however, presents a climatological characterization of summertime precipitation, defined as JulySeptember (JAS), in the Lake Mead watershed, located in the NAME Tier II region. Spatiotemporal variability of JAS rainfall is examined from 1981 to 2016 using gridded precipitation data and the meteorological mechanisms that account for this variability are investigated using reanalyses. The importance of the number of wet days (24-h rainfall $\geq 1 \mathrm{~mm}$ ) and extreme rainfall events (95th percentile of wet days) to the total JAS precipitation is examined and shows extreme events playing a larger role in the west and central basin. An investigation into the dynamical drivers of extreme rainfall events indicates that anticyclonic Rossby wave breaking (RWB) in the midlatitude westerlies over the U.S. West Coast is associated with $89 \%$ of precipitation events $>10 \mathrm{~mm}$ (98th percentile of wet days) over the Lake Mead basin. This is in contrast to the NAME Tier I region where easterly upper-level disturbances such as inverted troughs are the dominant driver of extreme precipitation. Due to the synoptic nature of RWB events, corresponding impacts and hazards extend beyond the Lake Mead watershed are relevant for the greater U.S. Southwest.
\end{abstract}

\section{Introduction}

Enhanced knowledge of Colorado River basin hydrometeorology is necessary for effective water resource management throughout the arid U.S. Southwest. This need is increasing in urgency given future projections of prolonged regional drought and growing water demand (U.S. Department of the Interior Bureau of Reclamation 2012). Accordingly, this manuscript presents a characterization of summertime meteorology over the Lake Mead watershed in the lower Colorado River basin.

Lake Mead supplies water to over 25 million people for household use, agriculture, and power generation across the U.S. Southwest (Rosen et al. 2012). While roughly $90 \%$ of annual inflow is generated via upstream releases from Lake Powell on the Colorado River (primarily fed by snowmelt in the upper Colorado River basin), $10 \%$ of inflow is generated locally (Bunk 2018), $25 \%$ of which occurs during the months of JulySeptember (JAS) (streamflow data available at https:// waterdata.usgs.gov/usa/nwis/). Although the average

Corresponding author: Michael D. Sierks, msierks@ucsd.edu annual inflow contributed by summertime precipitation within the Lake Mead watershed represents only a fraction of overall storage, multidecadal drought and historical overallocation of existing water resources have placed the reservoir on the precipice of a litigated shortage threshold that, when crossed, will trigger delivery cutbacks. As a result, interannual variability in this comparatively small inflow contribution by local summertime precipitation is highly relevant to overall water resource management and can be the difference between normal or historically unprecedented reservoir operations.

The precipitation events that generate summertime inflow to Lake Mead occur during the North American monsoon (NAM) season. The NAM is the main driver of summertime climate variability in the region and is associated with a marked increase in precipitation during the months of July, August, and September (Adams and Comrie 1997). Weather associated with the NAM can have devastating impacts on the built environment such as flooding, wind damage, dust storms, power outages, and crop loss (Brazel and Nickling 1986; Ray et al. 2007). Apart from hazards, precipitation falling during the monsoon season is vital for ecosystem processes 
TABLE 1. USGS gauge ID and geographical characteristics of the delineated subbasins and the entire Lake Mead watershed.

\begin{tabular}{lccrr}
\hline \multicolumn{1}{c}{ Watershed } & Abbreviated name & USGS gauge ID & Area $\left(\mathrm{km}^{2}\right)$ & $\begin{array}{r}\text { Mean/maximum } \\
\text { elevation }(\mathrm{m})\end{array}$ \\
\hline 1) Las Vegas Wash & LVW & 09419700 & 4900 & $1222 / 3601$ \\
2) Muddy River & MUD & 09419000 & 18200 & $1624 / 3479$ \\
3) Lower Lake Mead & LLM & 09404200 & 19500 & $1047 / 2463$ \\
4) Virgin River & VIR & 09415000 & 12700 & $1575 / 3225$ \\
5) Paria River & PAR & 09382000 & 3700 & $1874 / 3135$ \\
6) Grand Canyon & GCN & 09404200 & 25300 & $1761 / 3156$ \\
7) Little Colorado River & LCO & 09402000 & 68000 & $1922 / 3836$ \\
Combined watershed & - & - & 152300 & $1676 / 3836$ \\
\hline
\end{tabular}

(Notaro et al. 2010), which can affect the surface energy balance (Vivoni 2012; Watts et al. 2007) and feedback on summer precipitation (Dominguez et al. 2008; Small 2001).

Meteorologically, the NAM is characterized by the development of a surface heat low and 500-hPa "monsoon ridge" over the U.S. Southwest (Adams and Comrie 1997; Douglas 1995; Douglas et al. 1993; Tang and Reiter 1984). The subsequent seasonal reversal of winds and enhanced moisture transport into northwest Mexico and the southwestern United States at this time are essential to the development of precipitation, though it has been demonstrated for the North American Monsoon Experiment (NAME) Tier I region that synoptic-scale variability in the strength and position of the NAM ridge influences the organization and growth of convective systems and drives precipitation variability across a range of spatial and temporal scales (Bieda et al. 2009; Carleton 1986, 1987; Fuller and Stensrud 2000; Higgins et al. 2004; Johnson et al. 2007; Pascale and Bordoni 2016; Pytlak et al. 2005; Stensrud et al. 1997). For example, the interactions between the monsoon ridge and easterly disturbances, such as inverted troughs, are often associated with moisture surges and extreme precipitation in southern Arizona and northern Mexico (Brenner 1974; Hales 1974; Lahmers et al. 2016; Pytlak et al. 2005; Stensrud et al. 1997). Midlatitude westerly disturbances (e.g., cutoff lows, open wave troughs, short waves) have also been shown to produce synoptic forcing for ascent and low-level moisture transport into the NAM region leading to extreme precipitation (Carleton 1986; Corbosiero et al. 2009; Favors and Abatzoglou 2013; Johnson et al. 2007).

Here, we investigate the role of synoptic disturbances on NAM precipitation in the Lake Mead watershed in the NAME Tier II region, where considerably less is known about the impact of the individual mechanisms discussed above (Higgins and Gochis 2007). Motivated by the gap in understanding of hydrometeorology in the northern extent of the NAM, the ecological and societal impacts of monsoon rainfall, and declining Lake Mead reservoir elevations, the purpose of this manuscript is to examine the impact of summertime (JAS) precipitation on the Lake Mead watershed from a climatological perspective and to understand the synoptic drivers of regional extreme precipitation events.

\section{Data and methods}

\section{a. Watershed subdivisions}

To examine spatial variability across the Lake Mead watershed, USGS stream gauges on major Lake Mead tributaries were used to define seven subbasins (Table 1, Fig. 1). For each tributary, the farthest downstream gauge with the longest record of daily discharge was used to delineate the subbasin boundary (except for the Colorado River, which was split into two watersheds using a single USGS gauge).

\section{b. Precipitation}

Daily precipitation totals, defined as 1200-1200 UTC, were obtained from the PRISM 4-km gridded AN81d dataset for the period 1981-2016 (Daly et al. 1994). The individual subbasins are reasonably sampled by PRISM precipitation stations, although fewer exist in the proximity of the Grand Canyon. Although the onset and retreat of the NAM varies interannually, this work uses the months of JAS as a proxy for "monsoon season/ summertime," which generally agrees with Bieda et al. (2009) for the NAME Tier II region. The spatial variability of seasonal (JAS) precipitation within the Lake Mead basin was examined in addition to the temporal variability of precipitation on subseasonal, seasonal, and interannual time scales. One such metric used to infer relative interannual variability is the coefficient of variation $\left(c_{v}\right)$ hereby defined as $c_{v}=$ standard deviation/mean. Note that this metric is always positive and normalizes the variability by the mean of a given distribution.

To understand the drivers of interannual variability in total JAS precipitation, the relationship between the number of wet days as well as accumulation from extreme and nonextreme precipitation to the total JAS 


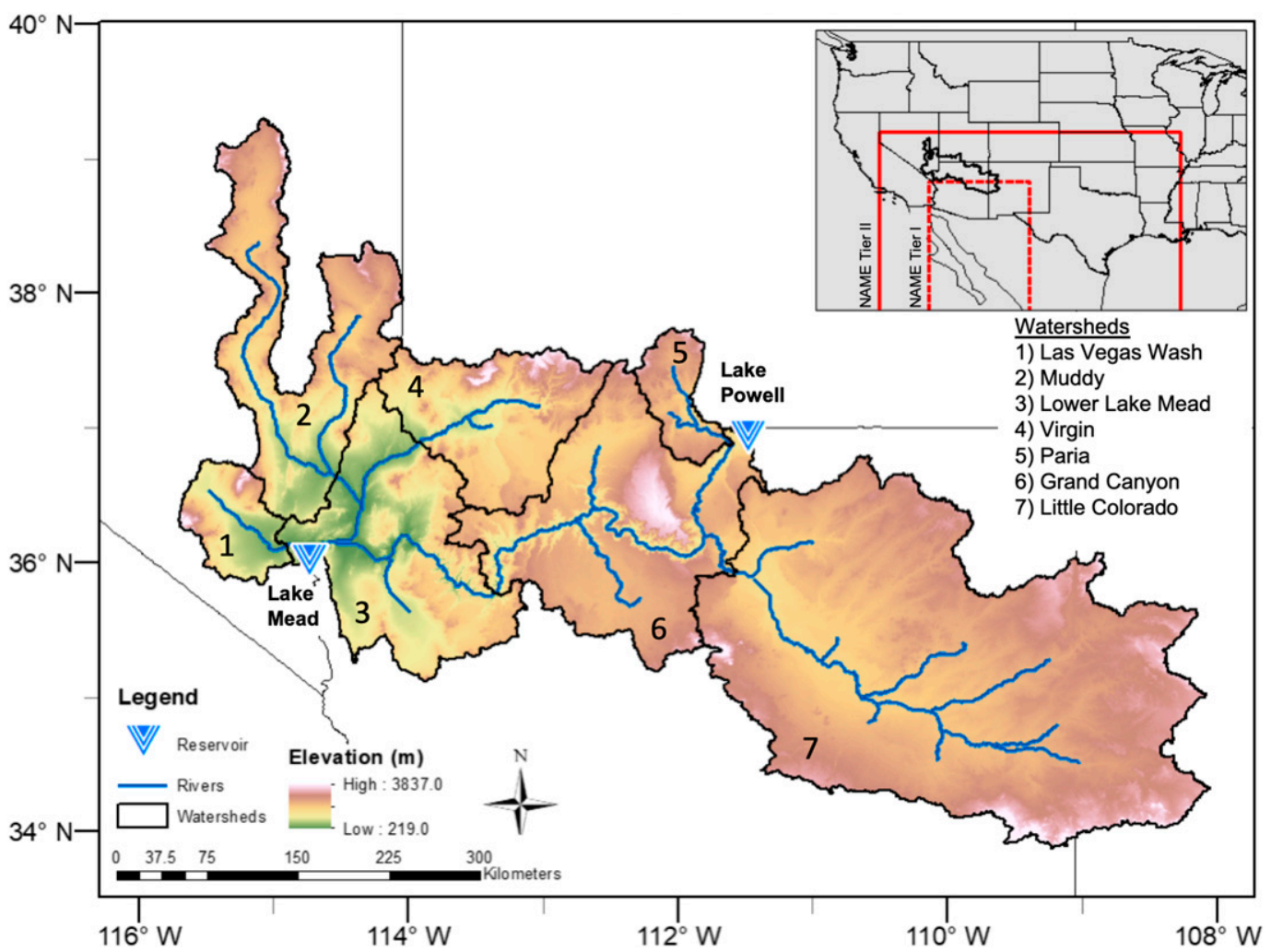

FIG. 1. Topography of the Lake Mead watershed including major tributaries and their subbasins. The northern extent of the NAME Tier I and II regions and the extent of the entire Lake Mead watershed below Lake Powell are shown in the inset for reference.

precipitation were independently examined using Spearman's rank correlation. Extreme (nonextreme) events were categorized as the 95th $(<95$ th $)$ percentile of wet days, defined here as 24-h mean basin precipitation $\geq 1 \mathrm{~mm}$ (Cavazos et al. 2008). Extreme events must be separated by more than one day to be considered independent and consecutive days $>95$ th percentile were counted as a single event on the first extreme precipitation date. The contribution of the top $5 \%$ of wet days to the JAS precipitation total was assessed for each subbasin and the entire Lake Mead watershed using the methodology of Dettinger and Cayan (2014).

\section{c. Meteorology}

Atmospheric reanalysis variables from NASA's Modern-Era Retrospective Analysis for Research and Applications, version 2 (Gelaro et al. 2017), were taken at 23 vertical levels from 1000 to $200 \mathrm{hPa}$ at $0.5^{\circ} \times 0.625^{\circ}$ horizontal resolution. Daily mean (1200-1200 UTC) values were computed by averaging across 3-hourly model output. Synoptic conditions for extreme events were examined via lagged composite analysis and on a case-bycase basis. Atmospheric conditions were examined 10 days prior through 1 day after each extreme precipitation event. Attention was focused on evaluating synoptic features identified in previous studies as important for southwest extreme precipitation, including: tropical easterly waves (Fuller and Stensrud 2000; Stensrud et al. 1997), inverted troughs (Bieda et al. 2009; Pytlak et al. 2005), upper-level potential vorticity anomalies (Carleton 1986; Pytlak et al. 2005), and 500-hPa ridge position (Carleton 1986, 1987; Maddox et al. 1995; Watson et al. 1994), in addition to integrated water vapor (IWV), and integrated vapor transport (IVT) (Schmitz and Mullen 1996).

Field significance for synoptic patterns was computed via bootstrapping with resampling in which the distribution of 5000 randomly selected representative data is compared to an individual event or composite signal. If the individual event or composite signal falls beyond the top or bottom $2.5 \%$ of the randomly selected distribution, the signal is deemed statistically significant. Standard anomalies for the above variables were computed using the following formula, standard anomaly = (data - climatology)/standard deviation, where the climatology and standard deviation were computed using a centered 28-day window across the 36-yr record at each grid point for each variable. 

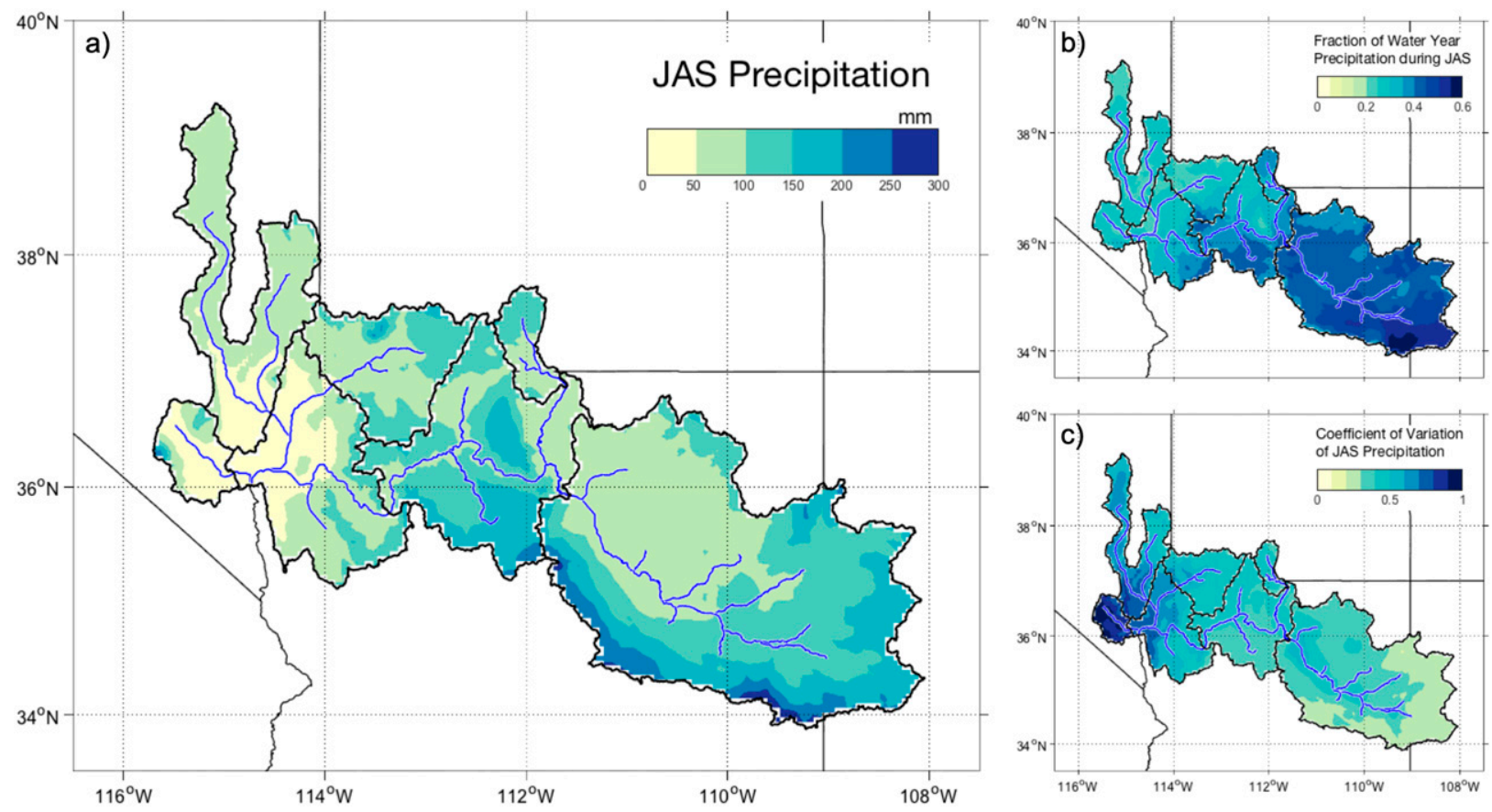

FIG. 2. Average characteristics for subbasins for (a) JAS precipitation, (b) fraction of water year precipitation during JAS, and (c) coefficient of variation of JAS precipitation derived from daily PRISM precipitation from 1981 to 2016.

\section{d. Tropical cyclone inventory}

To quantify the importance of tropical cyclones to JAS precipitation in the Lake Mead watershed, intensity and position were taken from the International Best Track Archive for Climate Stewardship (IBTrACS) dataset (Knapp et al. 2010) to identify tropical cyclone (TC) tracks that passed through $28.5^{\circ} \pm 2^{\circ} \mathrm{N}, 113.5^{\circ} \pm$ $3^{\circ} \mathrm{W}$. This region was chosen primarily to identify and flag TCs which track northeast enough to directly influence precipitation over the study area and encapsulates the core region of TC tracks impacting the southwest in Corbosiero et al. (2009). Similar to Seastrand et al. (2015), precipitation falling within 7 days from the flagged date was assumed to be associated with the concurrent TC. Flagged dates were excluded from the extreme event synoptic composite and case-by-case study to investigate drivers of extreme precipitation apart from tropical storms, which can produce extreme precipitation events in the study region but are infrequent enough to necessitate separate consideration in the climatology.

\section{Results}

\section{a. Climatology of JAS precipitation}

The average JAS total precipitation in the entire Lake Mead watershed is $103.0 \pm 32.6 \mathrm{~mm}$. Summertime rainfall maxima occur over high terrain features such as the
Mogollon Rim, Kaibab Plateau, and other isolated peaks (Fig. 2). The highest average values are located in the southeastern basin, on the northern side of the Mogollon Rim, which bifurcates the low deserts of southwestern Arizona from higher terrain to the north. On the subbasin scale, a strong increasing west-east gradient in average JAS precipitation exists with $57.2 \pm 46.9 \mathrm{~mm}$ falling in the westernmost Las Vegas Wash subbasin and 128.2 \pm $33.0 \mathrm{~mm}$ in the easternmost Little Colorado subbasin. In contrast, a strong decreasing west-east gradient exists in the coefficient of variation of average JAS precipitation. In general, the western subbasins are drier on average with larger interannual variability while the eastern basins are wetter with smaller interannual variability (Table 2). Further, the fraction of annual water year (WY; 1 October-30 September) precipitation occurring during JAS over the entire Lake Mead watershed is $36 \% \pm$ $13 \%$. A similar increasing west-east gradient is found with $29 \%$ of annual WY precipitation occurring in the Las Vegas Wash subbasin compared to $44 \%$ over the Little Colorado (Table 2).

\section{b. Relationship between number of wet days and total JAS precipitation}

The total number of wet days during JAS explains $75 \%$ of the year-to-year variability in total summertime precipitation for the Lake Mead watershed. In contrast to the coefficient of variation and contribution to annual 
TABLE 2. Precipitation characteristics of the delineated subbasins and the entire Lake Mead watershed.

\begin{tabular}{|c|c|c|c|c|c|c|c|}
\hline Watershed & $\begin{array}{l}\text { Average JAS } \\
\text { precipitation } \\
(\mathrm{mm})\end{array}$ & $\begin{array}{l}\text { WY fraction } \\
\text { during JAS }\end{array}$ & $\begin{array}{l}\text { Coefficient } \\
\text { of variation }\end{array}$ & $\begin{array}{c}\text { 1981-2016 JAS } \\
\text { minimum } \\
\text { (year) }\end{array}$ & $\begin{array}{c}\text { 1981-2016 JAS } \\
\text { maximum } \\
\text { (year) }\end{array}$ & $\begin{array}{l}\text { Average percent of } \\
\text { JAS precipitation } \\
\text { falling as extremes }\end{array}$ & $\begin{array}{l}\text { Percentage of total } \\
\text { JAS precipitation } \\
\text { falling as extremes } \\
\quad(1981-2016)\end{array}$ \\
\hline 1) LVW & $57 \pm 47$ & 0.29 & 0.82 & 9.7 (2010) & 230.7 (1984) & $12 \pm 22$ & 24.6 \\
\hline 2) MUD & $68 \pm 38$ & 0.25 & 0.56 & $17.1(1995)$ & $167.2(1984)$ & $14 \pm 18$ & 20.4 \\
\hline 3) LLM & $69 \pm 22$ & 0.30 & 0.48 & 21.8 (1993) & 142.4 (1984) & $14 \pm 19$ & 19.6 \\
\hline 4) VIR & $99 \pm 43$ & 0.30 & 0.44 & $36.1(2009)$ & $187.1(2004)$ & $16 \pm 18$ & 20.9 \\
\hline 5) PAR & $101 \pm 40$ & 0.34 & 0.40 & $41.0(2009)$ & $190.6(2003)$ & $17 \pm 17$ & 21.0 \\
\hline 6) $\mathrm{GCN}$ & $126 \pm 43$ & 0.35 & 0.34 & $51.5(2009)$ & $215.2(2013)$ & $17 \pm 14$ & 19.9 \\
\hline 7) $\mathrm{LCO}$ & $128 \pm 33$ & 0.44 & 0.26 & $54.1(2009)$ & 203.0 (1999) & $17 \pm 13$ & 17.8 \\
\hline $\begin{array}{l}\text { Combined } \\
\text { watershed }\end{array}$ & $103 \pm 33$ & 0.36 & 0.32 & $42.5(2009)$ & 181.2 (1984) & $15 \pm 12$ & 17.6 \\
\hline
\end{tabular}

precipitation results shown above, a west-east trend is not apparent, with rank correlated $r$-squared values falling between 0.65 and 0.77 .

The relationship between the mean total number of wet days during JAS and mean total JAS precipitation for each subbasin is shown in Fig. 3 and demonstrates a distinct difference between the western and easternmost subbasins' precipitation distributions. (For an individual basin, mean values of each variable mark the center of an ellipse, and the distance from the center to the ellipse's edge in either direction represents \pm 1 standard deviation of that variable. Data from individual years are shown in translucent dots.) In the Las Vegas Wash basin, the narrow vertical ellipse indicates comparative greater variability in total JAS precipitation than in the number of wet days during JAS. By comparison, the basins in the center of the greater Lake Mead watershed have more proportional variability in each variable. The easternmost Little Colorado River basin, as well as the entire Lake Mead watershed, is characterized by more consistent total JAS precipitation despite larger variability in the number of wet days. In general, basins increase in both total JAS precipitation and number of wet days moving from west to east.

\section{c. Relationship between extreme events and JAS total precipitation}

For the entire Lake Mead watershed, the variance in total JAS precipitation explained by the top $5 \%$ (bottom $95 \%$ ) of wet days is $46 \%(80 \%)$. Total variance explained exceeds $100 \%$ due to the correlation between precipitation regimes (i.e., years with extreme precipitation often have larger nonextreme totals). The average percentage of JAS precipitation falling as extremes ranges from $12 \%$ to $17 \%$, with slightly higher values in the eastern subbasins. When the percentage of total JAS precipitation from 1981 to 2016 falling as extremes is examined, western and central basins are more strongly influenced, with $24.6 \%$ of all precipitation due to extremes in the Las Vegas Wash and the combined watershed receiving $17.6 \%$ (Table 2).

\section{d. Seasonality of extreme events and tropical cyclones}

The monthly distribution of independent extreme precipitation events in the Lake Mead basin exhibits a skewness toward the end of the monsoon season (Fig. 4). In fact, the Little Colorado is the only subbasin for which July is not the month with the lowest frequency of extreme events, irrespective of TC inclusion. Concerning TCs, which occur preferentially toward the end of the JAS period, extreme (nonextreme) precipitation events are associated with $29 \%(67 \%)$ of systems that tracked into the region of influence (described in section $2 \mathrm{~d}$ ). While it is noteworthy that TCs are associated with a greater

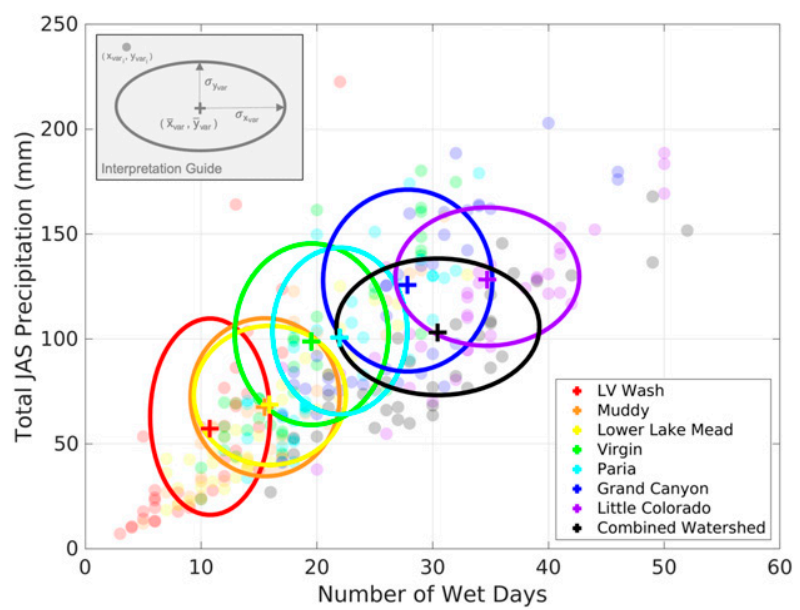

FIG. 3. Relationship between total seasonal JAS precipitation and number of wet days per JAS for each basin. The 36-yr mean values are denoted by "+" and individual years by translucent markers. The distance from the center of an ellipse to its edge in either axis dimension represents one standard deviation of that variable. Basins are ordered west-east corresponding to warm-tocool colors. 


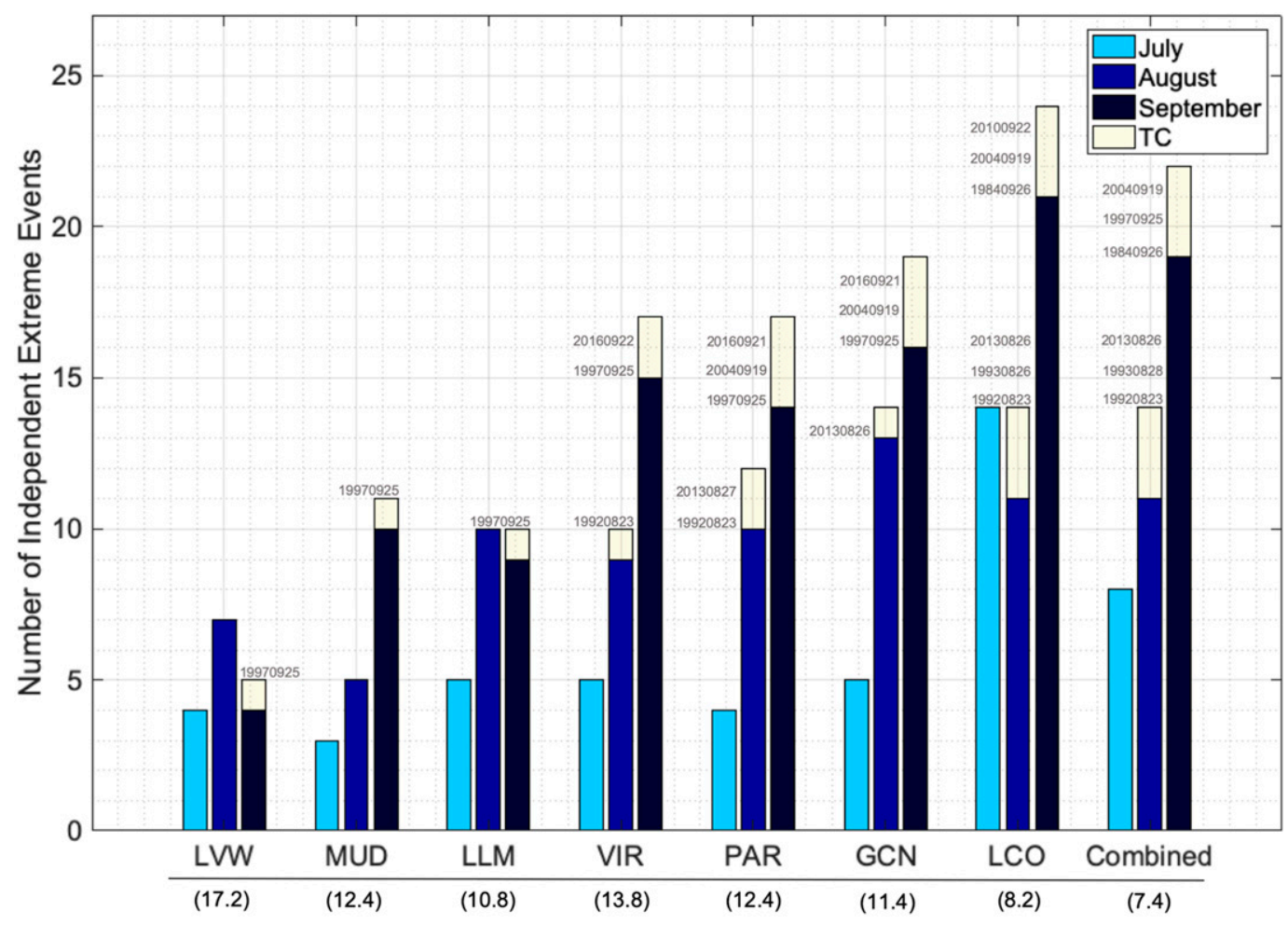

FIG. 4. Seasonal distribution of extreme events color coded by month for each subbasin with 95th percentile precipitation values $(\mathrm{mm})$ shown in parentheses. Extreme events within 7 days of tropical systems tracking within $28.5^{\circ} \pm 2^{\circ} \mathrm{N}$ and $-113^{\circ} \pm 3^{\circ} \mathrm{E}$ are denoted with corresponding event date in gray. Extreme precipitation events affecting multiple subbasins are counted once for each subbasin.

fraction of both extreme and nonextreme events in the eastern Lake Mead basin than the west, a thorough analysis of their meteorology and hydrologic impacts on the Tier II region is beyond the scope of this paper.

\section{e. Dynamical drivers of extreme events}

The meteorological conditions leading to extreme precipitation events, excluding TC events, for each subbasin as well as the combined Lake Mead basin were investigated using lagged composite and individual event analyses. Lagged composites show a weak westerly disturbance signal (not shown), though considerable variance necessitated a review of each individual event's meteorology. Further qualitative inspection of daily mean fields for each case revealed 4 distinct synoptic regimes: inverted trough, Rossby wave breaking in the midlatitude westerlies, tropical storm influence for non-TC flagged date, and uncharacterized.

Criteria for the above categories are as follows. Inverted trough (IV): westward-moving 200-hPa positive potential vorticity (PV) standard anomaly $>0.25$ on the southern side of the NAM ridge (Lahmers et al. 2016) poleward of $15^{\circ} \mathrm{N}$. Rossby wave breaking (RWB): eastward-moving 200-hPa positive PV standard anomaly $>0.25$ in midlatitudes with mandatory overturning of $2 \mathrm{PV}$ unit (PVU; $1 \mathrm{PVU}=10^{-6} \mathrm{~K} \mathrm{~kg}^{-1} \mathrm{~m}^{2} \mathrm{~s}^{-1}$ ) contour (Abatzoglou and Magnusdottir 2006; Postel and Hitchman 1999; Thorncroft et al. 1993). Tropical storm (TS): moisture surge coinciding with northward moving cyclonic feature off Baja coast, likely a tropical disturbance no longer tracked by IBTrACS and not associated with RWB or IV synoptics. Uncharacterized: no clear synoptic upper-level forcing mechanism, excessive moisture and low- to midlevel disturbances are possible.

RWB events were split into three groups: "canonical," "TC tapping," and "irregular" events. Canonical and TC tapping events feature clean Rossby wave breaking [e.g., Abatzoglou and Magnusdottir 2006 (note their Fig. 3); Barnes and Hartmann 2012 (note their Fig. 2)], with the latter potentially advecting moisture from a distinct cyclonic feature outside of the control box described in section $2 \mathrm{~d}$. Irregular RWB events feature an overturning of the 2 PVU contour, but with a less organized large-scale background flow. It is important to note that events were categorized using daily mean fields and analysis performed on higher temporal resolution data, for example, 3-hourly fields, may yield slightly different results. For example, an irregular RWB 

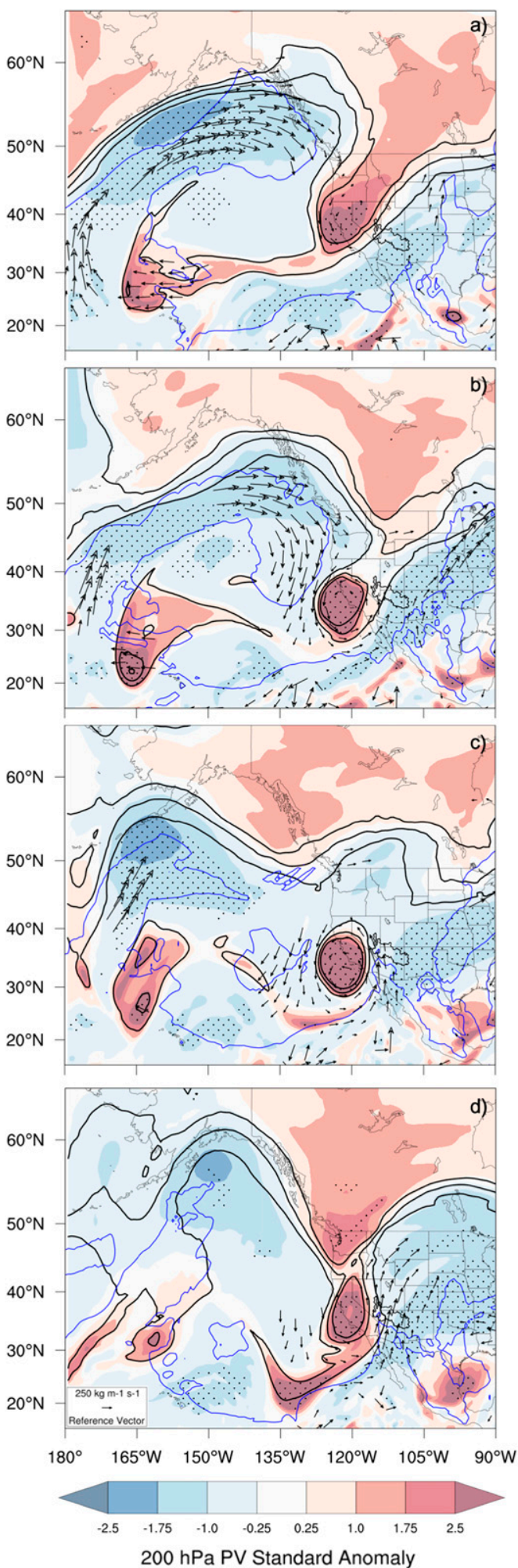

FIG. 5. Example of a "canonical" Rossby wave break extreme precipitation event. 200-hPa potential vorticity standardized anomaly (shaded), 200-hPa potential vorticity (black contours, shaded every 2 PVU starting at 2 PVU), and IWV (blue contour denoting 33-mm isoline) for (a) $20 \mathrm{Sep}$, (b) $21 \mathrm{Sep}$, (c) $22 \mathrm{Sep}$, and (d) $23 \mathrm{Sep}$ here may look canonical at higher resolution. However, changes to the large-scale synoptic categorization of events are unlikely.

Out of 40 independent extreme events for the combined Lake Mead watershed, $70 \%$ are classified as RWB events (canonical-22.5\%, TC tapping-17.5\%, irregular-30\%). Conversely, IVs are associated with $20 \%$ of all extreme events while TS and Uncharacterized events each comprise $5 \%$ of cases. Results for subbasins elucidate a similar trend with RWB playing a more dominant role than IVs in extreme events. The subjective analysis here suggests a preference for IV extreme events to occur early in the summer, peaking in July, waning in August, and absent for September. In contrast, RWB events play an increasing role as the summer progresses, associated with $\sim 40 \%-50 \%$ of July events compared to $\sim 90 \%$ of events in September. Independent extreme precipitation event dates for the combined Lake Mead watershed are listed by synoptic category in Table A1 in appendix A. On occasions where both a RWB and IV were identified $(n=2)$, preference was given to the most salient feature; one case was a RWB, the other an IV.

The extreme event on 23 September 2007 is an example of a canonical Rossby wave break event (Fig. 5). Here, the anticyclonic wave break 3 days prior to the event (Fig. 5a) produced a quasi-stationary cutoff low centered over the California Bight while simultaneously transporting significant amounts of water vapor poleward on the western flank. Although not all RWB events produce a cutoff low, the feature is common and the location of the positive (negative) 200-hPa PV (500-hPa height) anomaly is located to the west of the Lake Mead watershed. As the westerly trough dropped into the coastal region, the 500-hPa NAM ridge receded to the east. The resulting south-southwesterly synoptic-scale flow advected warm, moist air into the Lake Mead watershed providing necessary moisture for extreme precipitation. The progression of the northern edge of the 33-mm integrated water vapor (IWV) contour demonstrates the surge of moist air into the region (Figs. 5b,c) as a direct result of the anomalous cyclonic circulation. Last, quasigeostrophic dynamics associated with the cutoff low and leading edge of the positive PV anomaly can act as a trigger for intense convective storms (Hoskins et al. 1985; Martius and Rivière 2016). The

2007. The extreme precipitation event occurred on 23 Sep 2007. IVT vectors significant at the 95th percentile are shown. Stippling indicates statistical significance of 200-hPa PV standard anomaly at the 95th percentile. The Lake Mead watershed is outlined in a thin black line. 


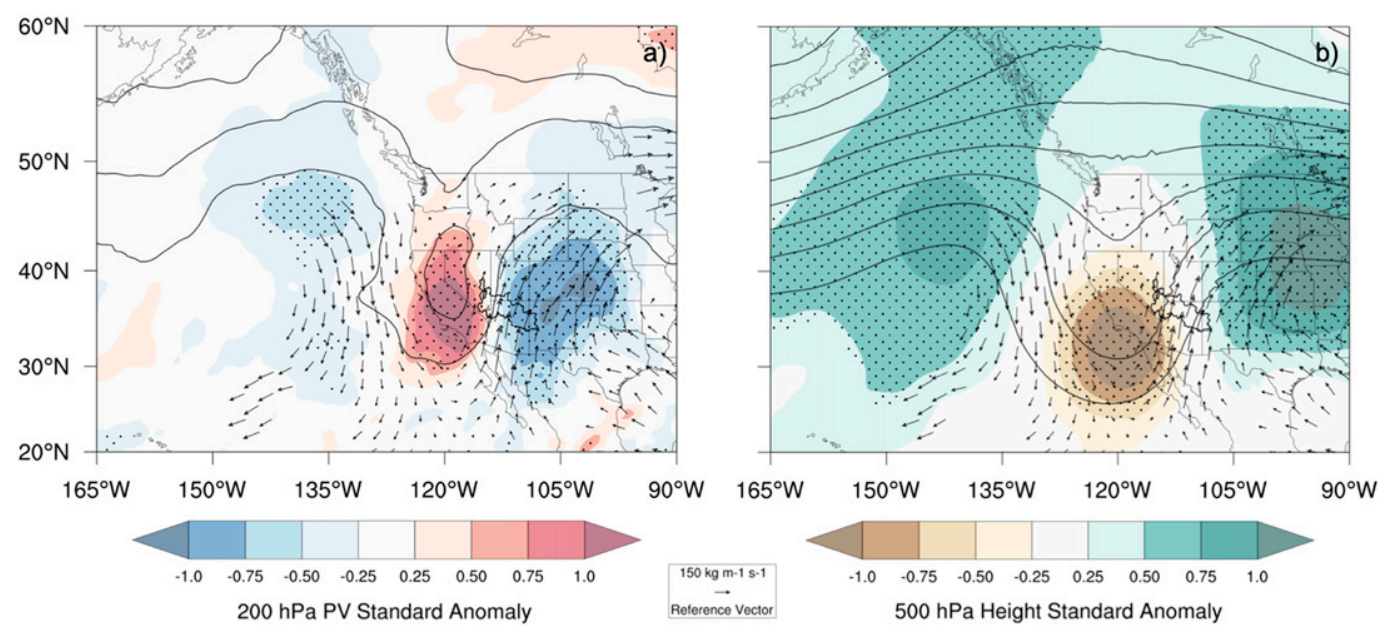

FIG. 6. Composite fields for combined "canonical" and "TC tapping" RWB cases $(n=16)$ in the combined Lake Mead watershed on day of extreme precipitation for (a) 200-hPa potential vorticity standardized anomaly (shaded) and 200-hPa potential vorticity (black contours, shaded every 2 PVU starting at 2 PVU), and (b) 500-hPa geopotential height standardized anomaly (shaded) and 500-hPa geopotential height (black contours, shaded every $50 \mathrm{~m}$ starting at $5850 \mathrm{~m}$ ). IVT vectors significant at the 95 th percentile are shown. Stippling indicates statistical significance of standard anomaly field at the 95 th percentile. The Lake Mead watershed is outlined in a thin black line.

24- and 72-h precipitation fields from this event can be viewed in appendix B as Figs. B1 and B2, respectively. This example serves to illustrate the general mechanisms by which an anticyclonic RWB generates extreme precipitation in the summertime southwestern United States, though the specific meteorology of any given RWB event is variable.

Lead-lag composite analysis was performed on the combined canonical and TC tapping RWB subset of extreme events for the combined Lake Mead watershed (Fig. 6). The composited atmospheric features are not sensitive to the choice of subbasin as the large-scale patterns for extreme precipitation are similar across the watershed. The composites do not depict a robust overturning of PV contours seen in Fig. 5 on account of variability in the location, timing, and axis of the wave break between events. Despite the weakened composite signal at long lead times, the synoptic features of a RWB are apparent with decreasing lead time and at the time of the precipitation event: collocated 200-hPa PV and $500-\mathrm{hPa}$ geopotential anomalies over the Southern California Bight, moist south-southwest flow into the U.S. Southwest, and a distinct Rossby wave pattern spanning the eastern Pacific and United States. It is worth noting that although the moist south-southwest flow is driven by the cyclonic circulation associated with the RWB, anticyclonic circulation (south-southeast flow) around an eastward displaced NAM ridge amplifies it. Further, the west-east dipole of cyclonic and anticyclonic circulation favors upper-level divergence that is conducive for ascent over the Lake Mead watershed
(Holton 2004). The composited days comprise $40 \%$ of JAS extreme events over the combined Lake Mead watershed, demonstrating the importance of midlatitude westerly disturbances to extreme precipitation in the NAME Tier II region.

To contrast RWB precipitation generation to inverted trough (IV) events, which are known to impact southern Arizona (Douglas and Englehart 2007; Finch and Johnson 2010; Pytlak et al. 2005), lead-lag composite analysis was applied to the IV subset of events for the combined Lake Mead watershed (Fig. 7). As in the RWB analysis, the composited large-scale atmospheric features are not sensitive to the choice of subbasin as the general synoptic patterns for extreme precipitation are similar across the watershed. However, the composited IV signal is less robust than the RWB as there is greater variability in the strength and location of the upper-level disturbance across the 8 individual IV events. At 2-3 days lead, the composites depict an easterly PV anomaly at 200-hPa with a weak 500-hPa geopotential height trough moving across northern Mexico on the equatorward side of a strengthened northward-displaced NAM ridge (not shown). From here, the monsoon ridge retreats eastward as the upper-level disturbance turns northward near the Baja Peninsula. The day of event composite features significant moisture transport into the Lake Mead watershed from the south-southeast as the collocated 200$\mathrm{hPa} \mathrm{PV}$ and $500-\mathrm{hPa}$ anomalies move northward across the U.S.-Mexico border. In addition to the northward moving upper-level disturbance, the day of event composite depicts a second 200-hPa positive PV anomaly off 

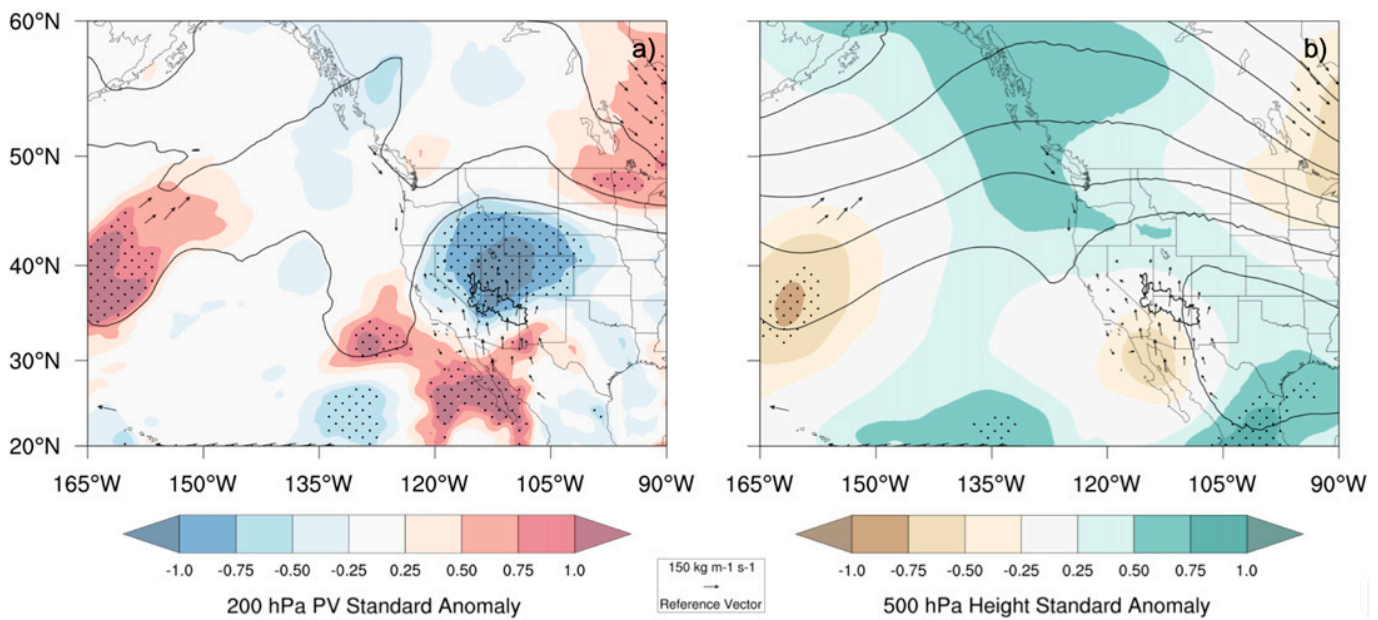

FIG. 7. Composite fields for IV cases $(n=8)$ in the combined Lake Mead watershed on day of extreme precipitation for (a) 200-hPa potential vorticity standardized anomaly (shaded) and 200-hPa potential vorticity (black contours, shaded every 2 PVU starting at 2 PVU), and (b) 500-hPa geopotential height standardized anomaly (shaded) and 500-hPa geopotential height (black contours, shaded every $50 \mathrm{~m}$ starting at $5850 \mathrm{~m}$ ). IVT vectors significant at the 95th percentile are shown. Stippling indicates statistical significance of standard anomaly field at 95th percentile. The Lake Mead watershed is outlined in a thin black line.

of the California coast whose ensuing circulation can help steer the primary disturbance toward the Lake Mead watershed (seen in several individual events). The composite 24-h precipitation field for RWB and IV cases can be seen in Figs. B3 and B4, respectively.

To contrast the temporal evolution of RWB and IV events, composite Hovmöller plots of 200-hPa PV, 700$\mathrm{hPa}$ meridional wind $(\mathrm{V} 700 \mathrm{hPa})$, and IWV are shown for each event type (Fig. 8). The composites include 16 RWB and $8 \mathrm{IV}$ events that produced extreme precipitation in the combined Lake Mead watershed. Because driving RWB and IV dynamics tend to occur in distinct latitudinal bands, each regime's PV field is averaged over its characteristic domain (detailed in Fig. 8). The latitudinal averaging band for the RWB composite $\left(32^{\circ}-45^{\circ} \mathrm{N}\right)$ is consistent with the region of $>0.5$ standard anomaly in Fig. 6 and that of the IVs $\left(25^{\circ}-35^{\circ} \mathrm{N}\right)$ is consistent with previous IV tracking work and highlights the northern portion of the domain used in Lahmers et al. (2016).

The RWB PV composite Hovmöller shows a distinct westerly wave with a couplet of maximum amplitude centered over the watershed on the day of extreme precipitation with an eastward propagation speed of roughly $350 \mathrm{~km} \mathrm{day}^{-1}$ (Fig. 8a). Dynamical forcing associated with the advection of positive $\mathrm{PV}$ at the feature's leading edge is conducive to ascent and likely plays a role in driving these extreme precipitation events (Hoskins et al. 1985; Martin 2006; Martius and Rivière 2016). The evolution of V700 hPa depicts significant circulation anomalies corresponding to the breakdown and eastward retreat of the NAM ridge due to an approaching midlatitude westerly disturbance (Fig. 8b). The evolution of IWV features a plume of moisture developing over the watershed several days prior to the event before reaching a maximum on the day of the event and then moving eastward (Fig. 8c).

In contrast, the PV composite for IV events features an easterly trough whose signal is evident several days prior to the extreme event. Both the primary easterly disturbance and the emergence of a secondary offshore PV anomaly can be seen (Fig. 8a). Anomalous southerly winds approaching the basin from the east are representative of an easterly disturbance in synchrony with an eastward or northward displaced NAM ridge (Fig. 8b). The IWV signal for the IVs emerges from the east $\sim 3$ days prior near $110^{\circ} \mathrm{W}$ and continues westward through the day of extreme precipitation (Fig. 8c).

\section{Discussion}

Deconstructing the Lake Mead watershed into subbasins reveals dramatic gradients in summertime (JAS) precipitation characteristics. Not only are the southeastern subbasins wetter than the northwestern, on average, they experience a greater fraction of water year precipitation during the summer months and less interannual variability of summer precipitation. Using a threshold of $1 \mathrm{~mm}$, the influence of the number of wet days on JAS accumulated precipitation exhibits no spatial trend with rank correlated $r$ squared values falling between 0.65 and 0.77 .

However, the role of extreme precipitation events in driving JAS total accumulation varies geographically in 
$32^{\circ} \mathrm{N}-45^{\circ} \mathrm{N}$ Mean $200 \mathrm{hPa}$ PV Standard Anomaly

$25^{\circ} \mathrm{N}-35^{\circ} \mathrm{N}$ Mean $200 \mathrm{hPa}$ PV Standard Anomaly
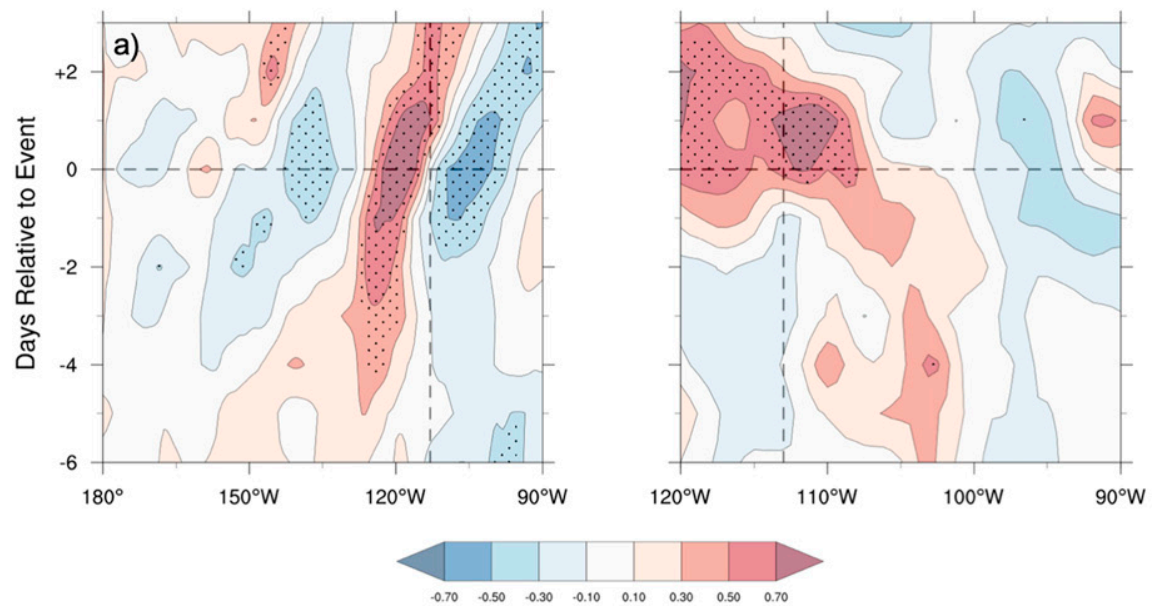

$25^{\circ} \mathrm{N}-35^{\circ} \mathrm{N}$ Mean V700hPa Standard Anomaly
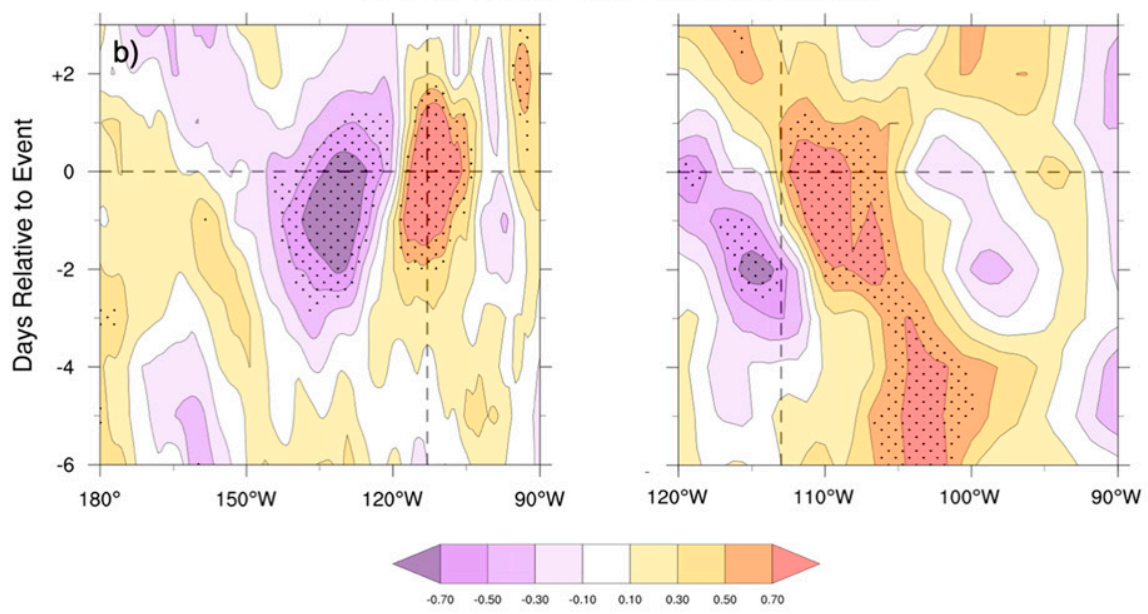

$25^{\circ} \mathrm{N}-35^{\circ} \mathrm{N}$ Mean IWV Standard Anomaly
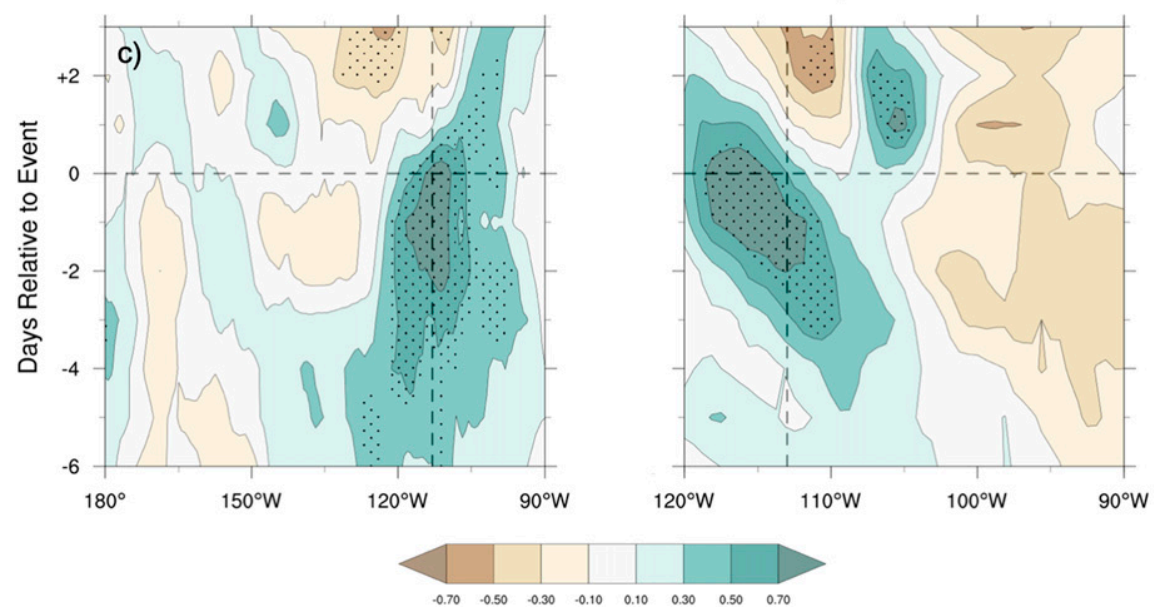

FIG. 8. Hovmöller plots of standardized anomalies for (a) 200-hPa potential vorticity, (b) 700 hPa meridional wind, and (c) integrated water vapor. (left) RWB events $(n=16)$ and (right) IV events $(n=8)$ for extreme precipitation events for the combined Lake Mead watershed. Stippling indicates statistical significance of the standardized anomaly field at the 95th percentile. 


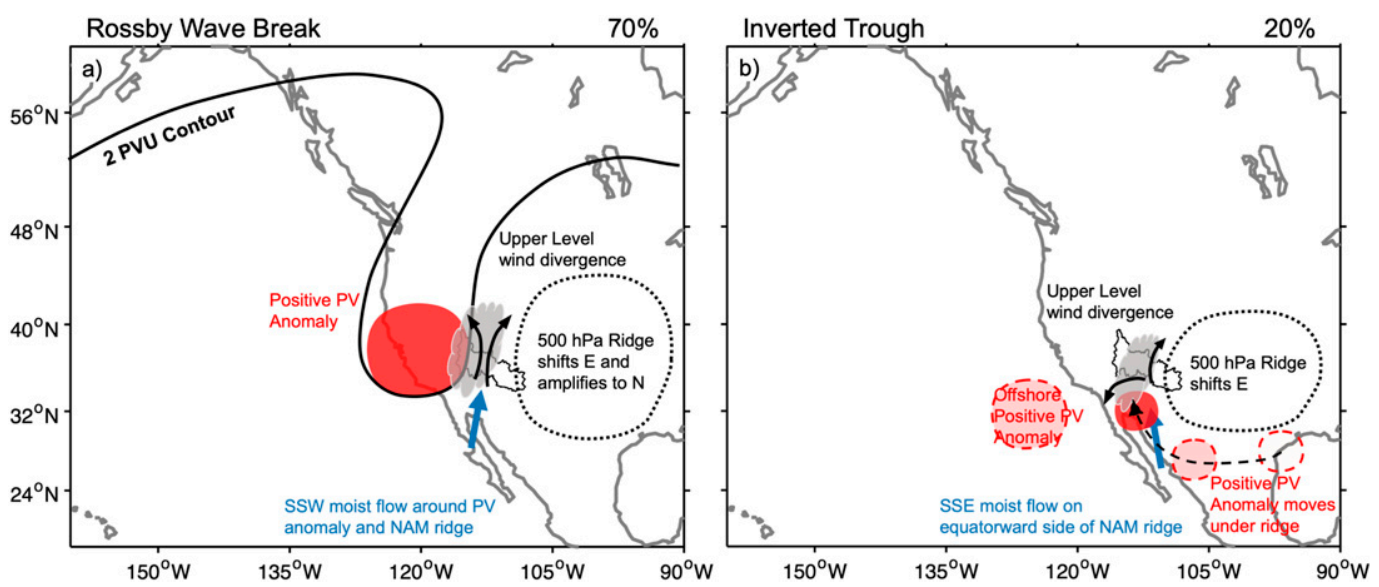

FIG. 9. Idealized synoptic setups for primary drivers of extreme precipitation in the Lake Mead watershed: (a) RWB, (b) IV (adapted from Pytlak et al. 2005), and their corresponding characteristic meteorology. The fraction of extreme events for the entire Lake Mead watershed associated with each regime is denoted above each panel. The Lake Mead watershed is outlined in a thin black line.

the Lake Mead basin with heightened importance in the central and western subbasins with $17.6 \%$ of $1981-2016$ JAS precipitation falling during extreme events for the combined Lake Mead watershed. Concerning the seasonality of extreme events, a skewness exists with distributions peaking in August or September across all subbasins. While this timing corresponds to increased tropical storm activity in the late summer, we find the relationship to hold when excluding tropical storms tracking within $28.5^{\circ} \pm 2^{\circ} \mathrm{N}, 113.5^{\circ} \pm 3^{\circ} \mathrm{W}$ from our analyses, suggesting landfalling tropical storms and their remnants are not the most frequent drivers of extreme precipitation in the late summer.

Case-by-case analyses of synoptic fields for each extreme event reveal anticyclonic Rossby wave breaking (RWB) in the midlatitude westerlies to be the dominant source of JAS extreme precipitation events in the entire Lake Mead watershed $(70 \%$ of events from 1981 to 2016). Interestingly, when the precipitation threshold for an extreme event is raised from the 95th percentile $(7.4 \mathrm{~mm})$ to the $98 \mathrm{th}$ percentile $(10 \mathrm{~mm})$, the fraction of RWB events increases from $70 \%$ to $89 \%$ indicating that RWB are associated with the most extreme summertime precipitation in the Lake Mead basin. The RWB results in a trough over the U.S. West Coast whose equatorward extent can reach as far south as $30^{\circ} \mathrm{N}$ (e.g., Fig. 5). The ensuing circulation is able to advect moisture into the southwest, priming the region for instability and precipitation. Further, eastward displacement of the 500$\mathrm{hPa}$ NAM ridge results in a circulation dipole centered over the southwest, enhancing moisture transport from the south and favoring upper-level divergence. Finally, strong quasigeostrophic dynamics on the leading flank of the positive potential vorticity (PV) anomaly can force ascent and trigger convection (Hoskins et al. 1985; Martin 2006; Martius and Rivière 2016).

Previous work has noted the role of midlatitude westerly disturbances in both aiding (Carleton 1986; Corbosiero et al. 2009; Favors and Abatzoglou 2013; Johnson et al. 2007) and suppressing (Douglas and Englehart 2007; Fuller and Stensrud 2000) moisture influx and precipitation in the NAM region. This manuscript builds upon the former body of work arguing that an upstream midlatitude trough is not only able to facilitate the advection of moist air into the NAM region, but also contribute favorable dynamics for extreme precipitation. New to the understanding of extreme events in the NAM region is the importance of anticyclonic Rossby wave breaking on the genesis of cutoff and closed lows. While earlier work has demonstrated the link between RWB and cutoff lows (Baray et al. 2003; Ndarana and Waugh 2010; Nieto et al. 2008; Scott et al. 2001) and the ability of RWB (Hoskins et al. 1985; Martius and Rivière 2016) and cutoff lows (Abatzoglou 2016; R. Nieto et al. 2008; Oakley and Redmond 2014) to affect extreme precipitation, these works have not demonstrated the importance of these mechanisms during the NAM season, especially as they relate to Tier II.

In southern Arizona and the NAME Tier I region, tropical easterly waves (TEWs) and inverted troughs (IVs) are important to extreme precipitation and convective outbreaks (Mazon et al. 2016; Pytlak et al. 2005). Although these transient disturbances are associated with extreme precipitation north of the Mogollon Rim, this flow regime is only associated with $20 \%$ of extreme events for the combined Lake Mead watershed. As seen in Bieda et al. (2009) and Pytlak et al. (2005), Lake Mead was impacted by IVs both originating south of $30^{\circ} \mathrm{N}$ in 
the Gulf of Mexico region as well as those generated in the midlatitude westerlies which became entrained in the tropical easterlies upon RWB on the east side of the NAM ridge.

When placing the Lake Mead watershed in the geographical context of previous literature highlighting extreme summertime precipitation, it appears to be located at a hinge point of synoptic forcing. IV track density peaks over central Mexico and the southern tip of Baja California, which results in greater impacts (cloud-toground lightning, precipitation) south of the Mogollon Rim in northern Mexico and southern Arizona (Bieda et al. 2009; Lahmers et al. 2016). In contrast, the seasonal fraction of summertime precipitation from closed and cutoff lows in the interior western United States increases from south to north, with distinctly higher values seen north of the Arizona-Utah border (Abatzoglou 2016; Oakley and Redmond 2014). The Lake Mead watershed, and the broader region straddling the northern NAME Tier I-II boundary, is uniquely positioned to experience the dominant synoptic drivers of extreme summertime precipitation of both the intermountain west and the core of the NAM region.

Idealized schematics of both RWB and IV events driving extreme precipitation in the Lake Mead basin are depicted in Fig. 9, though the specific meteorology of any given event is variable. In accordance with a strengthening of the monsoon ridge, due to thermal expansion of the lower atmosphere with increasing global temperatures (Christidis and Stott 2015; Pascale et al. 2016), it is worth investigating whether there will be a future change in the prevalence of IVs impacting the Lake Mead region as these features may be displaced southward and westward away from the locus of high pressure (Lahmers et al. 2016; their Fig. 18). The subjective analysis here suggests a preference for IV extreme events to occur early in the summer, peaking in July, waning in August, and absent for September for the combined Lake Mead watershed, which resembles the seasonality of IV days presented in Lahmers et al. (2016) and Bieda et al. (2009). In contrast, RWB events make up roughly $90 \%$ of September events but play a lesser role in July $(\sim 40 \%-50 \%)$. The transition from boreal summer to fall is associated with a strengthening of the Pacific westerly jet and the propensity for later season RWBs coincides with an easterly shift in the jet exit region and corresponding eastward shift in the location of RWB (Abatzoglou and Magnusdottir 2006). Noting that RWB events tend to occur later in the summer season, it may be useful to look beyond JAS into the fall and early winter to better understand the impact of RWB on precipitation throughout the southwest. In addition to facilitating extreme weather on the eastern flank, dynamics on the western side of anticyclonic RWB events can result in significant poleward transport of water vapor, as seen in Fig. $5 \mathrm{a}$, with potential impacts on precipitation and radiative forcing in the Arctic (Liu and Barnes 2015; Stramler et al. 2011).

Further, the timing of peak RWB frequency (Abatzoglou and Magnusdottir 2006) coincides with increased tropical storm activity in the tropical eastern Pacific (Corbosiero et al. 2009). Although extreme events corresponding to TCs tracking close to the head of the Gulf of California were removed, cyclonic circulation associated with RWB can tap into tropical moisture from already-decayed systems or those whose tracks are south or southwest of our control box. A sensitivity test indicated a southwestward expansion of our control box has little impact on the number of extreme events removed or their seasonality. However, as noted in previous work (Corbosiero et al. 2009; Garza 1999; Wood and Ritchie 2014), tropical systems that do impact western Mexico and the southwestern United States typically gain their northward motion from a deep equatorward penetration of a midlatitude trough, making the study of RWB tropical-extratropical interactions in the region relevant to the broader scientific community.

The results from this study are applicable beyond the Lake Mead watershed. Depending on the orientation of the RWB axis and whether the resulting PV anomaly is advected to the northeast by the steering flow, intense precipitation can reach into the interior west. In fact, several events in the Virgin subbasin corresponded to heavy precipitation in the Salt Lake City, Utah, area and one canonical RWB that tapped into a weakening tropical depression resulted in near-record floods on the Rillito River outside of Tucson, Arizona (Saarinen et al. 1984). The RWB event from Fig. 5 produced widespread heavy precipitation (over $50 \mathrm{~mm}$ falling in California, Nevada, Arizona, and Utah) resulting in $43 \%$ of the JAS mean in the Virgin subbasin and $19 \%$ for the entire Lake Mead watershed. Along with hail, flash flooding, and even a tornado report in Orange County, California (National Oceanic and Atmospheric Administration Storm Events Database; see online at https://www.ncdc. noaa.gov/stormevents), the intense precipitation associated with this system also drove a postfire debris flow in Los Angeles, California (Cannon et al. 2011). This example clearly shows the ability of RWB to drive extreme precipitation, meaningful streamflow generation, and high impact weather in the Lake Mead basin and beyond.

\section{Conclusions}

This work presents a climatological characterization of summertime precipitation in the Lake Mead watershed, 
TABLE A1. Independent extreme precipitation event dates for the combined Lake Mead watershed as categorized by synoptic processes defined in section $3 \mathrm{e}$.

\begin{tabular}{|c|c|c|c|c|c|}
\hline RWB “canonical" & RWB “TC tapping”, & RWB “irregular” & Inverted trough & Tropical storm & Uncharacterized \\
\hline 10 Aug 1981 & 17 Aug 1983 & $6 \operatorname{Sep} 1981$ & 24 Aug 1982 & 16 Aug 1990 & 13 Aug 1982 \\
\hline 23 Jul 1984 & 30 Sep 1983 & 11 Sep 1982 & 25 Jul 1983 & 5 Sep 1998 & 4 Aug 2016 \\
\hline 19 Sep 1985 & 24 Sep 1986 & 24 Sep 1983 & 22 Jul 1986 & & \\
\hline 23 Sep 1990 & 8 Sep 2002 & 17 Jul 1987 & 23 Jul 1998 & & \\
\hline 11 Aug 1997 & 11 Sep 2002 & 21 Jul 1987 & 9 Jul 1999 & & \\
\hline 12 Sep 1998 & 23 Sep 2007 & 18 Aug 1987 & 30 Aug 2000 & & \\
\hline 22 Aug 2012 & 9 Sep 2014 & 6 Sep 1991 & 27 Jul 2013 & & \\
\hline 10 Sep 2013 & & 3 Sep 1994 & 4 Aug 2014 & & \\
\hline \multirow[t]{4}{*}{28 Sep 2014} & & 4 Sep 1997 & & & \\
\hline & & 12 Sep 2012 & & & \\
\hline & & 20 Aug 2014 & & & \\
\hline & & 8 Aug 2015 & & & \\
\hline
\end{tabular}

located in the NAME Tier II region, spanning from 1981 to 2016. The importance of the number of wet days (24-h rainfall $\geq 1 \mathrm{~mm}$ ) and extreme rainfall events (95th percentile of wet days) to the total JAS precipitation is examined and shows a strong west-east gradient of JAS precipitation with extreme events playing a larger role in the central and west basin. Anticyclonic Rossby wave breaking (RWB) over the U.S. West Coast is found to be the dominant synoptic driver of extreme summertime precipitation in the Lake Mead watershed. As the Lake Mead basin sits on the northern periphery of the more-studied North American Monsoon Experiment (NAME) Tier I region, this result highlights the different mechanisms associated with extreme precipitation to the north and south of the Mogollon Rim and may prove relevant for the greater NAME Tier II region.

Although some impacts of RWB on extreme precipitation in the Colorado River basin from a hydroclimate and flood risk standpoint are demonstrated here, there remains much to be learned. Earlier work has demonstrated that the lack of snowmelt and flashy nature of lower Colorado basin tributaries makes streamflow forecasting difficult (Shafer and Huddleston 1984); however, improving hydrologic model forcing (i.e., precipitation forecasting) may yield more accurate streamflow predictions (Franz et al. 2003). Noting the frequent collocation with cutoff lows, which have been associated with substantial forecast difficulty (Nieto et al. 2005; Smith et al. 2002), understanding the atmospheric regimes conducive to RWB over the U.S. West Coast may help improve accompanying precipitation and streamflow forecasts in the greater NAM region. Moving forward, it will be important employ a climatological framework to understand the necessary conditions (location/strength of upper-level low, land surface moisture, local sea surface temperatures, etc.) for a RWB event to facilitate extreme precipitation in the southwestern United States.
Looking toward the future, Oakley and Redmond (2014) note that since short- to medium-range numerical weather prediction models have difficulty regarding closed lows associated with RWB, long-term climate models likely face serious issues in representing these features as well. Further, uncertainties in the latitudinal position of the eddy driven jet and subsequent impacts on anticyclonic RWB (Barnes and Hartmann 2012) make the study of future RWB impacts on summertime precipitation in the NAM region challenging. Despite this, it is important to determine if and how RWB frequency over this region will be affected by a changing climate. Shifts in the longitudinal location, equatorward extent, and intensity of RWB will impact their ability to act as moisture conduits from the tropics to the NAM region and drive extreme precipitation, with potential implications for the future state of regional water resources.

Acknowledgments. The authors thank the three referees for their careful reviews and important comments that significantly improved the manuscript. This research was supported by the U.S. Army Corps of Engineers Grant USACE W912HZ-15-2-0019, and the CA Department of Water Resources Grant 4600010378 TO\#15 Am 22. The authors thank William Chapman for providing statistical guidance and Chad Hecht for illuminating synoptic discussions.

\section{APPENDIX A}

\section{Extreme Precipitation Events by Synoptic Categorization}

Following the criteria described in section $3 \mathrm{e}$, the date and synoptic categorization of individual extreme precipitation events impacting the entire Lake Mead watershed are given in Table A1. Note that tropical cyclones have been removed prior to analysis as noted in section $2 \mathrm{~d}$. 


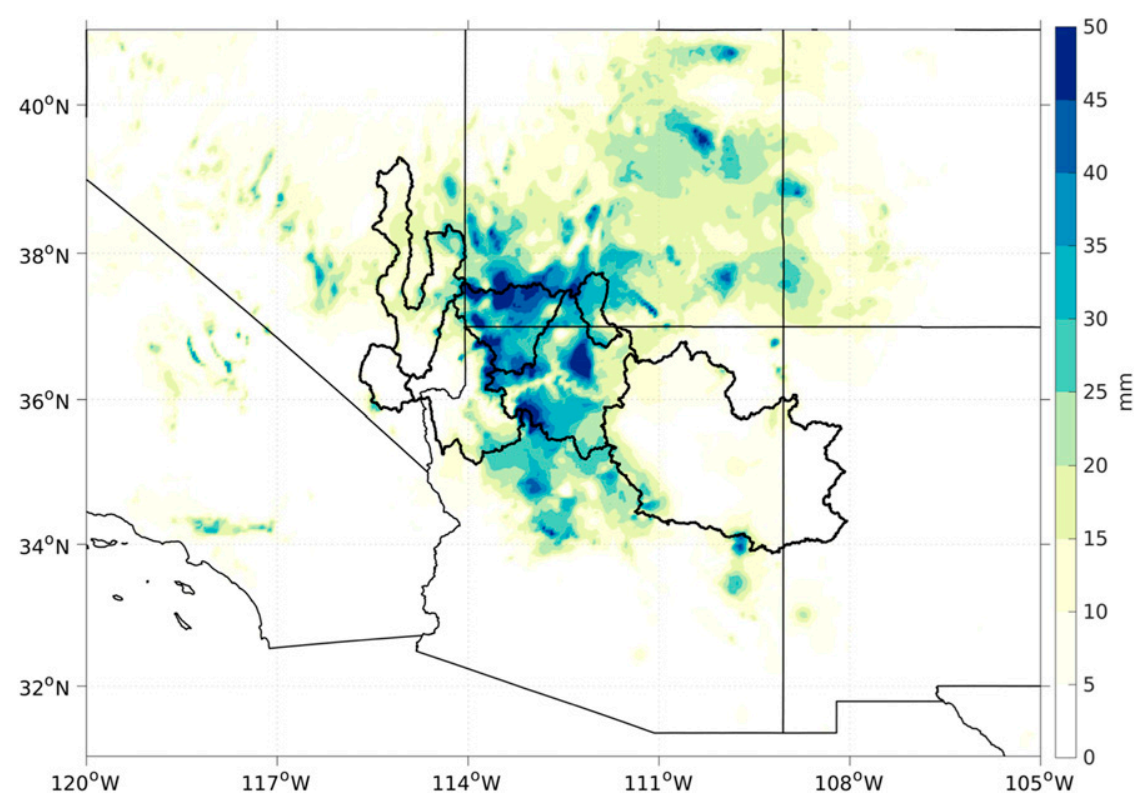

FIG. B1. 24-h PRISM precipitation field for an extreme precipitation event occurring on 23 Sep 2007, shown in Fig. 5 of the main text.

\section{APPENDIX B}

\section{Precipitation Distributions for Extreme Events in the Lake Mead Watershed}

The 24-h precipitation distribution (Fig. B1) for the event in Fig. 5 depicts a south-north swath of rainfall in accordance with the longitudinal circulation dipole seen in Fig. 5d. However, as the cutoff low moved from west to east during the $72 \mathrm{~h}$ centered about the extreme event day, the corresponding 72-h precipitation field appears as a zonal band of heavy precipitation (Fig. B2).

The composited 24-h precipitation distribution for the "canonical" and "TC tapping" RWB events from Fig. 6

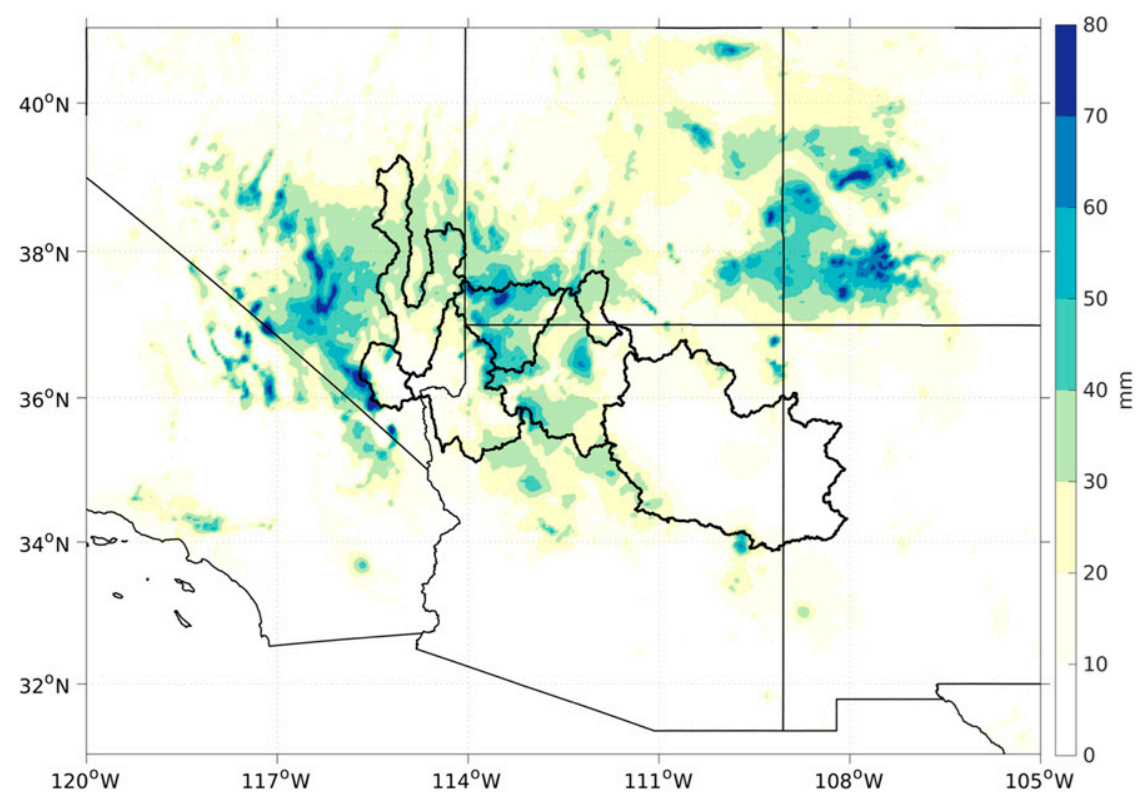

FIG. B2. 72-h PRISM precipitation field for an extreme precipitation event occurring on 23 Sep 2007, shown in Fig. 5 of the main text. Precipitation data cover 22 Sep, 23 Sep, and 24 Sep 2007. 


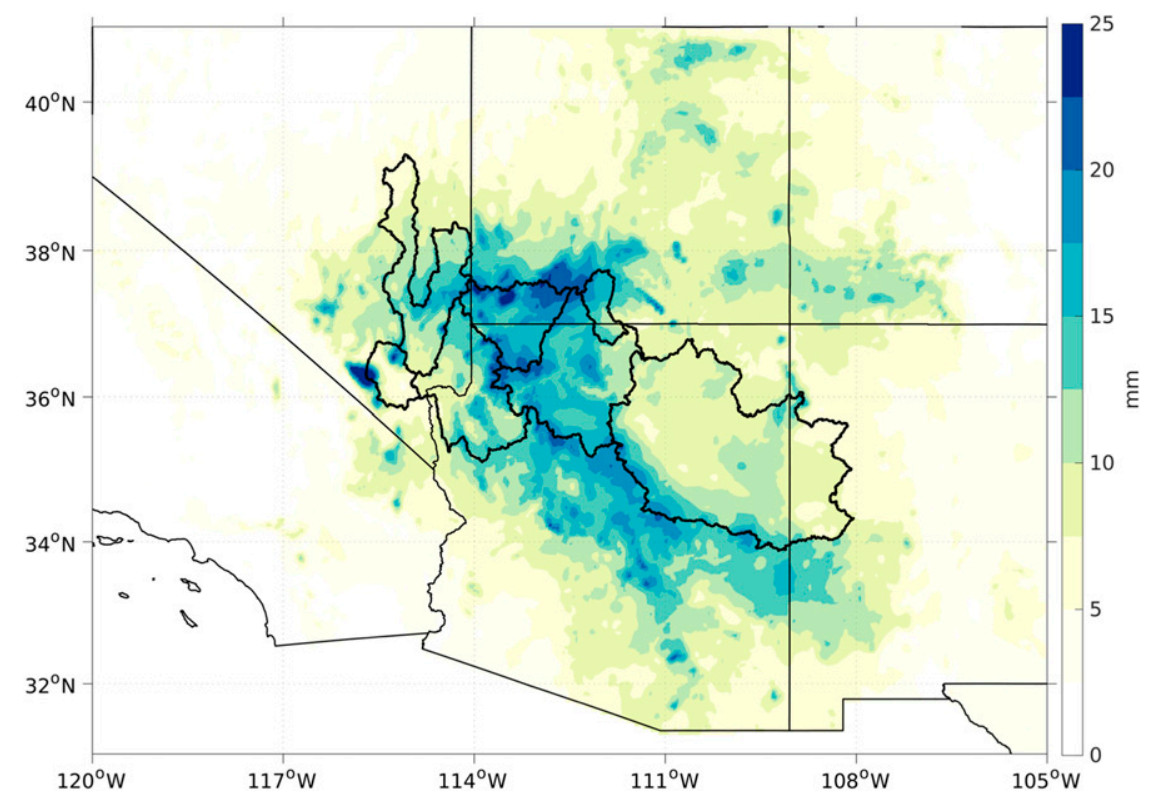

FIG. B3. 24-h PRISM precipitation composite for "canonical" and "TC tapping" RWB extreme precipitation events for the combined Lake Mead watershed $(n=16)$ used to create Fig. 6 of the main text.

depicts a meridional swath of rainfall spanning southern Arizona to Utah (Fig. B3). Although individual events differ in orientation, location, and precipitation amount, the composited distribution indicates the ability of RWB events to impact the greater NAM region.
Compared to Fig. B3, the composite precipitation values for IV events are noticeably smaller, supporting the argument that RWB events are the main drivers of the most extreme precipitation events in the Lake Mead watershed (Fig. B4).

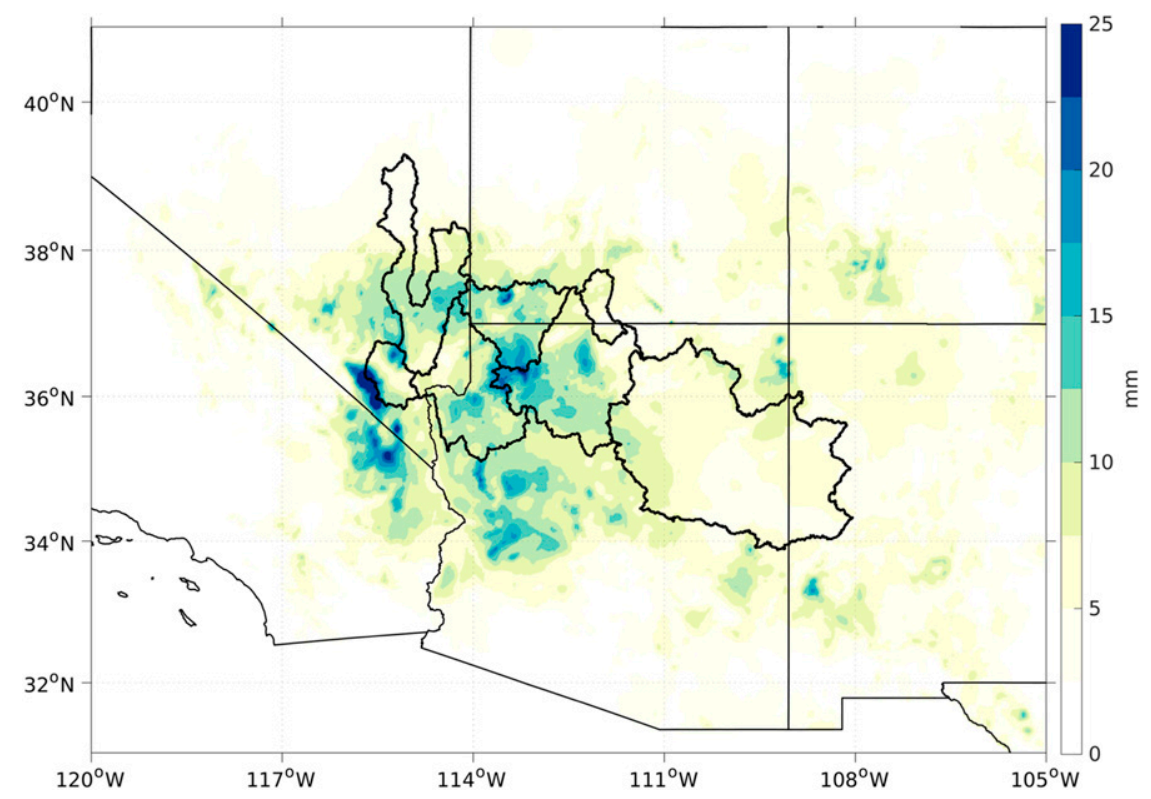

FIG. B4. 24-h PRISM precipitation composite centered around the day of extreme precipitation for IV events for the combined Lake Mead watershed $(n=8)$ used to create Fig. 7 of the main text. 


\section{REFERENCES}

Abatzoglou, J. T., 2016: Contribution of cutoff lows to precipitation across the United States. J. Appl. Meteor. Climatol., 55, 893899, https://doi.org/10.1175/JAMC-D-15-0255.1.

__ , and G. Magnusdottir, 2006: Planetary wave breaking and nonlinear reflection: Seasonal cycle and interannual variability. J. Climate, 19, 6139-6152, https://doi.org/10.1175/ JCLI3968.1.

Adams, D. K., and A. C. Comrie, 1997: The North American monsoon. Bull. Amer. Meteor. Soc., 78, 2197-2213, https://doi.org/ 10.1175/1520-0477(1997)078<2197:TNAM > 2.0.CO;2.

Baray, J., S. Baldy, R. Diab, and J. Cammas, 2003: Dynamical study of a tropical cut-off low over South Africa, and its impact on tropospheric ozone. Atmos. Environ., 37, 1475-1488, https:// doi.org/10.1016/S1352-2310(02)00999-8.

Barnes, E. A., and D. L. Hartmann, 2012: Detection of Rossby wave breaking and its response to shifts of the midlatitude jet with climate change. J. Geophys. Res., 117, 1-17, https://doi. org/10.1029/2012JD017469.

Bieda, S. W., C. L. Castro, S. L. Mullen, A. C. Comrie, and E. Pytlak, 2009: The relationship of transient upper-level troughs to variability of the North American monsoon system. J. Climate, 22, 4213-4227, https://doi.org/10.1175/2009JCLI2487.1.

Brazel, A. J., and W. G. Nickling, 1986: The relationship of weather types to dust storm generation in Arizona (1965-1980). J. Climatol., 6, 255-275, https://doi.org/10.1002/joc.3370060303.

Brenner, I. S., 1974: A surge of maritime tropical air-Gulf of California to the southwestern United States. Mon. Wea. Rev., 102, 375-389, https://doi.org/10.1175/1520-0493(1974)102<0375: ASOMTA $>2.0 . \mathrm{CO} ; 2$.

Bunk, D., 2018: Colorado River Basin: System status update and outlook for 2018 and 2019. Colorado River Citizens Forum, Yuma, Arizona, U.S. Department of the Interior Bureau of Reclamation, 15 pp., https://www.ibwc.gov/Files/CF_CO_ CRB_012418.pdf.

Cannon, S. H., E. M. Boldt, J. L. Laber, J. W. Kean, and D. M. Staley, 2011: Rainfall intensity-duration thresholds for postfire debris-flow emergency-response planning. Nat. Hazards, 59, 209-236, https://doi.org/10.1007/s11069-011-9747-2.

Carleton, A. M., 1986: Synoptic-dynamic character of 'bursts' and 'breaks' in the South-West U.S. summer precipitation singularity. J. Climatol., 6, 605-623, https://doi.org/10.1002/ joc.3370060604.

_ 1987: Summer circulation climate of the American Southwest, 1945-1984. Ann. Assoc. Amer. Geogr., 77, 619-634, https:// doi.org/10.1111/j.1467-8306.1987.tb00184.x.

Cavazos, T., C. Turrent, and D. P. Lettenmaier, 2008: Extreme precipitation trends associated with tropical cyclones in the core of the North American monsoon. Geophys. Res. Lett., 35, L21703, https://doi.org/10.1029/2008GL035832.

Christidis, N., and P. A. Stott, 2015: Changes in the geopotential height at $500 \mathrm{hPa}$ under the influence of external climatic forcings. Geophys. Res. Lett., 42, 10 798-10 806, https://doi.org/ 10.1002/2015GL066669.

Corbosiero, K. L., M. J. Dickinson, and L. F. Bosart, 2009: The contribution of eastern North Pacific tropical cyclones to the rainfall climatology of the Southwest United States. Mon. Wea. Rev., 137, 2415-2435, https://doi.org/10.1175/2009MWR2768.1.

Daly, C., R. P. Neilson, and D. L. Phillips, 1994: A statisticaltopographic model for mapping climatological precipitation over mountainous terrain. J. Appl. Meteor., 33, 140-158, https:// doi.org/10.1175/1520-0450(1994)033<0140:ASTMFM>2.0.CO;2.
Dettinger, M. D., and D. R. Cayan, 2014: San Francisco estuary and watershed science. Drought and the California Delta: A Matter of Extremes, San Francisco Estuary and Watershed Science Series, Vol. 12, John Muir Institute of the Environment, 1-6.

Dominguez, F., P. Kumar, and E. R. Vivoni, 2008: Precipitation recycling variability and ecoclimatological stability-A study using NARR data. Part II: North American monsoon region. J. Climate, 21, 5187-5203, https://doi.org/10.1175/2008JCLI1760.1.

Douglas, A. V., and P. J. Englehart, 2007: A climatological perspective of transient synoptic features during NAME 2004. J. Climate, 20, 1947-1954, https://doi.org/10.1175/JCLI4095.1.

Douglas, M. W., 1995: The summertime low-level jet over the Gulf of California. Mon. Wea. Rev., 123, 2334-2347, https://doi.org/ 10.1175/1520-0493(1995)123<2334:TSLLJO>2.0.CO;2.

_, R. A. Maddox, K. Howard, and S. Reyes, 1993: The Mexican monsoon. J. Climate, 6, 1665-1677, https://doi.org/10.1175/ 1520-0442(1993)006<1665:TMM>2.0.CO;2.

Favors, J. E., and J. T. Abatzoglou, 2013: Regional surges of monsoonal moisture into the southwestern United States. Mon. Wea. Rev., 141, 182-191, https://doi.org/10.1175/MWR-D12-00037.1.

Finch, Z. O., and R. H. Johnson, 2010: Observational analysis of an upper-level inverted trough during the 2004 North American Monsoon Experiment. Mon. Wea. Rev., 138, 3540-3555, https:// doi.org/10.1175/2010MWR3369.1.

Franz, K. J., H. C. Hartmann, S. Sorooshian, and R. Bales, 2003: Verification of National Weather Service ensemble streamflow predictions for water supply forecasting in the Colorado River Basin. J. Hydrometeor., 4, 1105-1118, https://doi.org/ 10.1175/1525-7541(2003)004<1105:VONWSE > 2.0.CO;2.

Fuller, R. D., and D. J. Stensrud, 2000: The relationship between tropical easterly waves and surges over the Gulf of California during the North American monsoon. Mon. Wea. Rev., 128, 2983-2989, https://doi.org/10.1175/1520-0493(2000)128<2983: TRBTEW $>2.0 . \mathrm{CO} ; 2$.

Garza, A. L., 1999: 1985-1998 North Pacific tropical cyclones impacting the southwestern United States and northern Mexico: An updated climatology. NOAA Tech. Memo. NWS WR-258, 118 pp.

Gelaro, R., and Coauthors, 2017: The Modern-Era Retrospective Analysis for Research and Applications, version 2 (MERRA-2). J. Climate, 30, 5419-5454, https://doi.org/10.1175/JCLI-D16-0758.1.

Hales, J. E., 1974: Southwestern United States summer monsoon source-Gulf of Mexico or Pacific Ocean? J. Appl. Meteor., 13, 331-342, https://doi.org/10.1175/1520-0450(1974)013<0331: SUSSMS $>2.0 . \mathrm{CO} ; 2$.

Higgins, R. W., W. Shi, and C. Hain, 2004: Relationships between Gulf of California moisture surges and precipitation in the southwestern United States. J. Climate, 17, 2983-2997, https://doi.org/ 10.1175/1520-0442(2004)017<2983:RBGOCM>2.0.CO;2.

Higgins, W., and D. Gochis, 2007: Synthesis of results from the North American Monsoon Experiment (NAME) process study. $J$. Climate, 20, 1601-1607, https://doi.org/10.1175/JCLI4081.1.

Holton, J. R., 2004: An Introduction to Dynamic Meteorology. 4th ed. Elsevier Academic, 535 pp.

Hoskins, B. J., M. E. McIntyre, and A. W. Robertson, 1985: On the use and significance of isentropic potential vorticity maps. Quart. J. Roy. Meteor. Soc., 111, 877-946, https://doi.org/10.1002/ qj.49711147002.

Johnson, R. H., P. E. Ciesielski, B. D. McNoldy, P. J. Rogers, and R. K. Taft, 2007: Multiscale variability of the flow during the North American Monsoon Experiment. J. Climate, 20, 16281648, https://doi.org/10.1175/JCLI4087.1. 
Knapp, K. R., M. C. Kruk, D. H. Levinson, H. J. Diamond, and C. J. Neumann, 2010: The International Best Track Archive for Climate Stewardship (IBTrACS). Bull. Amer. Meteor. Soc., 91, 363-376, https://doi.org/10.1175/2009BAMS2755.1.

Lahmers, T. M., C. L. Castro, D. K. Adams, Y. L. Serra, J. J. Brost, and T. Luong, 2016: Long-term changes in the climatology of transient inverted troughs over the North American monsoon region and their effects on precipitation. J. Climate, 29, 60376064, https://doi.org/10.1175/JCLI-D-15-0726.1.

Liu, C., and E. A. Barnes, 2015: Extreme moisture transport into the Arctic linked to Rossby wave breaking. J. Geophys. Res. Atmos., 120, 3774-3788, https://doi.org/10.1002/2014JD022796.

Maddox, R. A., D. M. McCollum, and K. W. Howard, 1995: Large-scale patterns associated with severe summertime thunderstorms over central Arizona. Wea. Forecasting, 10, 763-778, https://doi.org/10.1175/1520-0434(1995)010<0763: LSPAWS $>2.0$.CO;2.

Martin, J. E., 2006: Mid-Latitude Atmospheric Dynamics: A First Course. Wiley, 336 pp.

Martius, O., and G. Rivière, 2016: Rossby wave breaking: Climatology, interaction with low-frequency climate variability, and links to extreme weather events. Dynamics and Predictability of Large-Scale, High-Impact Weather and Climate Events, J. Li et al., Eds., Cambridge University Press, 69-78, https://doi.org/ 10.1017/CBO9781107775541.006.

Mazon, J. J., C. L. Castro, D. K. Adams, H. I. Chang, C. M. Carrillo, and J. J. Brost, 2016: Objective climatological analysis of extreme weather events in Arizona during the North American monsoon. J. Appl. Meteor. Climatol., 55, 2431-2450, https:// doi.org/10.1175/JAMC-D-16-0075.1.

Ndarana, T., and D. W. Waugh, 2010: The link between cut-off lows and Rossby wave breaking in the Southern Hemisphere. Quart. J. Roy. Meteor. Soc., 136, 869-885, https://doi.org/ 10.1002/qj.627.

Nieto, R., and Coauthors, 2005: Climatological features of cutoff low systems in the Northern Hemisphere. J. Climate, 18, 30853103, https://doi.org/10.1175/JCLI3386.1.

_, M. Sprenger, H. Wernli, R. M. Trigo, and L. Gimeno, 2008: Identification and climatology of cut-off lows near the tropopause. Ann. N.Y. Acad. Sci., 1146, 256-290, https://doi.org/ 10.1196/annals.1446.016.

Notaro, M., Z. Liu, R. G. Gallimore, J. W. Williams, D. S. Gutzler, and S. Collins, 2010: Complex seasonal cycle of ecohydrology in the Southwest United States. J. Geophys. Res., 115, G04034, https://doi.org/10.1029/2010JG001382.

Oakley, N. S., and K. T. Redmond, 2014: A climatology of 500-hPa closed lows in the northeastern Pacific Ocean, 1948-2011. J. Appl. Meteor. Climatol., 53, 1578-1592, https://doi.org/ 10.1175/JAMC-D-13-0223.1.

Pascale, S., and S. Bordoni, 2016: Tropical and extratropical controls of Gulf of California surges and summertime precipitation over the southwestern United States. Mon. Wea. Rev., 144, 2695-2718, https://doi.org/10.1175/MWR-D-15-0429.1.

_ - and Coauthors, 2016: The impact of horizontal resolution on North American monsoon Gulf of California moisture surges in a suite of coupled global climate models. J. Climate, 29, 7911-7936, https://doi.org/10.1175/JCLI-D-16-0199.1.

Postel, G. A., and M. H. Hitchman, 1999: A climatology of Rossby wave breaking along the subtropical tropopause. J. Atmos. Sci., 56, 359-373, https://doi.org/10.1175/1520-0469(1999) 056<0359:ACORWB $>2.0 . \mathrm{CO} ; 2$.

Pytlak, E., M. Goering, and A. Bennett, 2005: Upper tropospheric troughs and their interaction with the North American
Monsoon. 19th Conf. on Hydrology, San Diego, CA, Amer. Meteor. Soc., JP2.3, https://ams.confex.com/ams/Annual2005/ techprogram/paper_85393.htm.

Ray, A. J., G. M. Garfin, M. Wilder, M. Vásquez-León, M. Lenart, and A. C. Comrie, 2007: Applications of monsoon research: Opportunities to inform decision making and reduce regional vulnerability. J. Climate, 20, 1608-1627, https://doi.org/10.1175/ JCLI4098.1.

Rosen, M. R., K. Turner, S. L. Goodbred, and J. M. Miller, 2012: A synthesis of aquatic science for management of Lakes Mead and Mohave. U.S. Geological Survey Circular 1381, U.S. Geological Survey, 162 pp., https://doi.org/10.3133/cir1381.

Saarinen, T. F., V. R. Baker, R. Durrenburger, and T. Maddock, 1984: The Tucson, Arizona, Flood of October 1983. National Academy Press, $112 \mathrm{pp}$.

Schmitz, J. T., and S. L. Mullen, 1996: Water vapor transport associated with the summertime North American monsoon as depicted by ECMWF analyses. J. Climate, 9, 1621-1634, https://doi.org/ 10.1175/1520-0442(1996)009<1621:WVTAWT>2.0.CO;2.

Scott, R. K., J.-P. Cammas, P. Mascart, and C. Stolle, 2001: Stratospheric filamentation into the upper tropical troposphere. J. Geophys. Res., 106, 11 835-11 848, https://doi.org/ 10.1029/2001JD900049.

Seastrand, S., Y. Serra, C. Castro, and E. Ritchie, 2015: The dominant synoptic-scale modes of North American monsoon precipitation. Int. J. Climatol., 35, 2019-2032, https://doi.org/ 10.1002/joc. 4104 .

Shafer, B. A., and J. M. Huddleston, 1984: Analysis of seasonal volume streamflow forecast errors in the western United States. Proc. A Critical Assessment of Forecasting in Water Quality Goals in Western Water Resources Management, Bethesda, MD, American Water Resources Association, 117-126.

Small, E. E., 2001: The influence of soil moisture anomalies on variability of the North American Monsoon System. Geophys. Res. Lett., 28, 139-142, https://doi.org/10.1029/ 2000GL011652.

Smith, B. A., L. F. Bosart, D. Keyser, and D. S. Jean, 2002: A global $500 \mathrm{hPa}$ cutoff cyclone climatology : 1953-1999. 19th Conf. on Weather Analysis and Forecasting/15th Conf. on Numerical Weather Prediction, San Antonio, TX, Amer. Meteor. Soc., P1.14, https://ams.confex.com/ams/SLS_WAF_NWP/techprogram/ paper_47082.htm.

Stensrud, D. J., R. L. Gall, and M. K. Nordquist, 1997: Surges over the Gulf of California during the Mexican monsoon. Mon. Wea. Rev., 125, 417-437, https://doi.org/10.1175/1520-0493(1997)125<0417: SOTGOC $>2.0 . \mathrm{CO} ; 2$.

Stramler, K., A. D. Del Genio, and W. B. Rossow, 2011: Synoptically driven Arctic winter states. J. Climate, 24, 17471762, https://doi.org/10.1175/2010JCLI3817.1.

Tang, M., and E. R. Reiter, 1984: Plateau monsoons of the Northern Hemisphere: A comparison between North America and Tibet. Mon. Wea. Rev., 112, 617-637, https://doi.org/10.1175/15200493(1984)112<0617:PMOTNH>2.0.CO;2.

Thorncroft, C. D., B. J. Hoskins, and M. E. McIntyre, 1993: Two paradigms of baroclinic-wave life-cycle behaviour. Quart. J. Roy. Meteor. Soc., 119, 17-55, https://doi.org/10.1002/ qj.49711950903.

U.S. Department of the Interior Bureau of Reclamation, 2012: Colorado River Basin water supply and demand study: Executive summary. U.S. Department of the Interior Bureau of Reclamation, 34 pp., https://www.usbr.gov/watersmart/bsp/ docs/finalreport/ColoradoRiver/CRBS_Executive_Summary_ FINAL.pdf. 
Vivoni, E. R., 2012: Diagnosing seasonal vegetation impacts on evapotranspiration and its partitioning at the catchment scale during SMEX04-NAME. J. Hydrometeor., 13, 1631-1638, https:// doi.org/10.1175/JHM-D-11-0131.1.

Watson, A. I., R. E. López, and R. L. Holle, 1994: Diurnal cloud-toground lightning patterns in Arizona during the Southwest monsoon. Mon. Wea. Rev., 122, 1716-1725, https://doi.org/ 10.1175/1520-0493(1994)122<1716:DCTGLP>2.0.CO;2.
Watts, C. J., R. L. Scott, J. Garatuza-Payan, J. C. Rodriguez, J. H. Prueger, W. P. Kustas, and M. Douglas, 2007: Changes in vegetation condition and surface fluxes during NAME 2004. J. Climate, 20, 1810-1820, https://doi.org/10.1175/JCLI4088.1.

Wood, K. M., and E. A. Ritchie, 2014: A 40-year climatology of extratropical transition in the eastern North Pacific. J. Climate, 27, 5999-6015, https://doi.org/10.1175/JCLID-13-00645.1. 